\title{
Identificación de las nulidades en los contratos estatales en Colombia
}

\author{
José LuIS BENAVIDES ${ }^{1}$
}

\section{RESUMEN}

El régimen jurídico de las nulidades de los contratos estatales se estructura a partir del régimen común del Código Civil, con excepción de algunas nulidades específicamente administrativas y los efectos de la declaratoria de nulidad absoluta en los contratos de tracto sucesivo. Pero al concretar la identificación de las distintas nulidades de los contratos públicos, de la mano de una jurisprudencia densa y poco homogénea, surgen abundantes especificidades que sacan a la luz la necesidad de una mejor comprensión de los elementos de validez de estos contratos.

Palabras clave: nulidades, nulidades administrativas, contratos públicos, validez del contrato, causales de nulidad.

\section{Identification of Nullities in Public Contracts in Colombia}

\section{ABSTRACT}

The legal regime applicable to nullities of public contracts is structured around the common regime found in the Civil Code, except for some specific

1 Doctor en Derecho Público de la Universidad de París I (Panthéon-Sorbonne), París Francia. Docente investigador del Departamento de Derecho Administrativo de la Universidad Externado de Colombia, Bogotá, Colombia. Correo-e: jose.benavides@uexternado. edu.co. Enlace ORCID: https://orcid.org/0000-0003-1338-6320. Fecha de recepción: 18 de agosto de 2020. Fecha de modificación: 10 de septiembre de 2020. Fecha de aceptación: 30 de septiembre de 2020. Para citar el artículo: BenAvides, José Luis, "Identificación de las nulidades en los contratos estatales en Colombia", Revista digital de Derecho Administrativo, Universidad Externado de Colombia, n. ${ }^{\circ} 25,2021$, pp. 55-107. DOI: https://doi. org/10.18601/21452946.n25.03. 
administrative nullities and the effects of the declaration of absolute nullity in continuing performance agreements. However, the identification of different nullities in public contracts, along with an ambiguous and inconsistent jurisprudence, produce several other singularities that bring to light the need for a greater understanding of the elements of validity of these contracts.

Keywords: Nullities, Administrative Nullities, Public Contracts, Validity of the Contract, Grounds for Nullity.

\section{INTRODUCCIÓN}

En concordancia con el régimen jurídico mixto de los contratos estatales concebido en el Estatuto General de la Contratación ${ }^{2}$, las nulidades contractuales se definen a partir de la referencia al derecho privado. El artículo 44 del Estatuto enuncia a manera liminar que "los contratos del Estado son absolutamente nulos en los casos previstos en el derecho común" para describir en seguida los cinco casos de nulidades especiales de estos contratos cuando: a) se celebren con personas incursas en causales de inhabilidad o incompatibilidad previstas en la Constitución y la ley; b) se celebren contra expresa prohibición constitucional o legal ${ }_{i}$ c) se celebren con abuso o desviación de poder $_{i}$ d) se declaren nulos los actos administrativos en que se fundamenten, y e) se hubieren celebrado con desconocimiento de los criterios previstos en el artículo 21 sobre tratamiento de ofertas nacionales y extranjeras o con violación de la reciprocidad de que trata esta ley.

El artículo 46 complementa la concepción, al establecer que

los demás vicios que se presenten en los contratos y que conforme al derecho común constituyen causales de nulidad relativa, pueden sanearse por ratificación expresa de los interesados o por el transcurso de dos (2) años contados a partir de la ocurrencia del hecho generador del vicio.

La remisión al derecho común nos lleva al Código Civil y su definición de nulidad a partir de la "falta de alguno de los requisitos que la ley prescribe para el valor" del contrato (artículo 1740), así como a la división esencial entre nulidades absolutas y relativas. Concepción y división de las nulidades que nos lleva también a recordar los requisitos para obligarse (artículo 1502) y poder identificar así los que dan lugar a una y otra nulidad: los vicios que afecten el objeto o la causa lícitos, así como la incapacidad absoluta de alguno de los contratantes (artículo 1504) generarán nulidad absoluta, mientras que la capacidad relativa y los vicios del consentimiento (error, fuerza o dolo) (artículos 1508-1516) generarán nulidad relativa. La concepción es reiterada 
en el Código de Comercio (C.co.) al enunciar las mismas causales de nulidad absoluta (artículo 899) y relativa (artículo 900).

La división binaria esencial de las nulidades delimita los diversos intereses protegidos por los elementos esenciales del contrato. Las nulidades absolutas se refieren a valores que interesan a la colectividad y no solo a las partes del contrato. Así, el artículo 1519 del Código Civil (C.C.) identifica de manera genérica el objeto ilícito con "todo lo que contraviene el derecho público de la Nación" y la causa ilícita como el motivo prohibido por la ley que induce al contrato o que resulta contrario a las buenas costumbres o al orden público (artículo 1524). Este interés protegido, que desborda el de las partes, hace indisponible para ellas la posibilidad de remediar la irregularidad mediante el saneamiento de estas nulidades, al punto que incluso el juez puede y debe (se insiste en el código) declararlas de oficio cuando aparezcan manifiestas en un proceso y las partes se encuentren presentes (artículo 1742). Por el contrario, las nulidades relativas protegen intereses particulares de las partes y por ello deberán ser alegadas por aquellos en cuyo beneficio se han establecido (C.C., artículo 1743 y C.co., artículo 900), quienes pueden por ello sanearlas. Más aún, su inactividad para hacer efectiva la protección jurídica mediante una solicitud judicial de nulidad del contrato hace que pierdan ese derecho, por cuanto prescribe en un término corto de dos años (C.co., artículo 900).

Esta concepción esencial de las nulidades y los derechos con ellas protegidos sería conservada, en principio, para los contratos estatales, dada la redacción del capítulo IV del Estatuto General, con algunas regulaciones especiales. La enumeración de unas nulidades absolutas especiales del artículo 44, transcritas arriba, se complementan con el poder de terminación unilateral otorgado a la Administración contratante cuando se presenten algunas de ellas (artículo 45) y los efectos de las nulidades en los contratos de ejecución sucesiva (artículo 48), no del todo ajenos al régimen general privado.

Sin embargo, al aproximarse al tema y apreciar la concreción específica de las nulidades en el contrato público, salen a flote muchas aspectos especiales fruto de la esencia misma del régimen de los elementos de validez del contrato $y$, con ellos, de los valores protegidos en el contrato. El enunciado del artículo 46 del Estatuto, que reitera el carácter relativo de toda nulidad no explícitamente calificada de absoluta y su ratificación expresa o por el transcurso de dos años, resulta de muy limitada aplicación. En realidad, el régimen de nulidad relativa es aplicable a los vicios que provengan del particular contratista. Cuando se trata de la Administración contratante, la concreción de los eventos de nulidad relativa tiene connotaciones particulares incompatibles.

La incapacidad absoluta, reservada por el Código Civil a los menores impúberes (artículo 1504 mod.) adquiere una noción extendida en las entidades estatales. La regla general de la capacidad de actuar del Código Civil (artículo 1503) contrasta con el principio de legalidad que caracteriza el comportamiento 
de la Administración. Esta noción esencial de la competencia conlleva la aplicación de dinámicas y reglas administrativistas complementarias, como la imposibilidad de saneamiento de vicios de incompetencia ${ }^{3}$. Las posibilidades de validación de los negocios privados por vicios de capacidad, así como su ratificación cuando se presentan problemas de representación de una persona o una sociedad, no son viables en caso de las entidades estatales contratantes. Cualquier problema de competencia constituirá un vicio esencial insanable y, por consiguiente, una nulidad absoluta.

Por otra parte, los vicios del consentimiento no estarán referidos a las nociones privadas de error, fuerza y dolo cuando estemos examinando su aplicación a la administración contratante. Su equivalente serán los errores, falencias o vicios de la concreción del consentimiento para contratar dado por la administración, lo que se traduce en una valoración del proceso de contratación, guiado por reglas particulares, todas de carácter administrativo. El consentimiento de la Administración se materializa en estos procedimientos de contratación que incluso van más lejos que la descripción de los mismos en las reglas legales y reglamentarias, en la medida en que la voluntad de la Administración se estructura de manera más temprana, a partir de la concepción misma del negocio jurídico que se va a suscribir, lo que incluye los distintos aspectos de planeación del contrato estatal. Aquí, también, la concepción de nulidad relativa será inaplicable, por cuanto todos los vicios que se presenten afectarán de manera esencial el proceso o tendrán una dinámica particular de solución, inspirada en la que gobierna los procedimientos administrativos. Ello explicaría la concepción particular del saneamiento de vicio del procedimiento o de forma que no den lugar a nulidades (ni absolutas ni relativas) previsto en el artículo 49 del Estatuto Contractual.

Siguiendo el referente del derecho privado, que en últimas sigue teniendo valor para guiar la apreciación de las particularidades del contrato público, podría modularse la calificación dual esencial de las nulidades subjetivas y objetiva en torno a las nulidades que afectan el funcionamiento de la Administración (1) y aquellas que contaminan el contrato mismo (2). La presentación del contenido de uno y otro permitirá apreciar los límites de la aplicación de la concepción de la teoría general del contrato privado anclada en la distinción esencial de protección de intereses individuales e intereses públicos que no es pertinente frente a los contratos públicos.

3 Consejo de Estado, Sala de lo Contencioso Administrativo, Sección Primera, sent. 03/12/1997, exp. 4.179; Consejo de Estado, Sala de lo Contencioso Administrativo, Sección Cuarta, sent. 12/07/2012, exp. 17.892. 


\section{AFECTACIÓN DEL FUNCIONAMIENTO DE LA ADMINISTRACIÓN}

En la concepción del contrato de derecho privado, las nulidades relativas están establecidas en beneficio de una de las partes, bien sea por las limitaciones de su capacidad (incapacidad relativa) o por los vicios en su consentimiento al momento de contratar (error, fuerza o dolo) ${ }^{4}$. Estas expresiones se adaptan mal a los elemento de validez del contrato estatal, por las particularidades de la competencia de las entidades estatales (1.1) y la particular formación del consentimiento de la administración que impone una apreciación especial de sus vicios (1.2).

\subsection{Problemas de capacidad (Competencia)}

En los contratos estatales la nulidad relativa por problemas de capacidad es aplicable a los contratistas privados, con la plena vigencia del artículo 46 de la Ley 80 de 1993, en virtud del cual los vicios no listados en el artículo 44 como nulidades absolutas son objeto de nulidad relativa. Por el contrario, la nulidad absoluta por incapacidad igualmente absoluta del Código Civil (artículos 1741 y 1504) se encuentra ampliada en la contratación del Estado.

Con relación a los contratistas, la primera causal de nulidad especial del artículo 44 concierne una institución inexistente en los contratos entre particulares: el régimen de inhabilidades e incompatibilidades de la contratación pública y su transgresión al suscribir el contrato. Este régimen no está establecido para proteger al contratista, como se regulan las incapacidades relativas en el derecho privado, sino para proteger intereses eminentemente públicos. En particular, el régimen tiene por objeto evitar situaciones generadoras de riesgo de parcialidad en la selección del contratista por sus vínculos con servidores públicos o con otros contratistas, o dejar de lado proponentes que no son recomendables para la buena ejecución del contrato por las faltas e incluso delitos que cometieron contra los intereses de la Administración pública, o apartar a los proponentes que han tenido vínculos estrechos con Administración. El Consejo de Estado entiende que la incompatibilidad se presenta por la imposibilidad de coexistencia de dos actividades en una persona, por cuanto ello reñiría con el cumplimiento estricto de cometidos públicos y contra el acceso en igualdad de condiciones a las oportunidades de contratación, mientras que la inhabilidad consiste en un impedimento o imposibilidad legal para acceder a la contratación estatal ${ }^{5}$. Aunque la distinción no es técnicamente clara en 
el régimen de contratación, lo esencial es que su fundamento concierne la moralidad pública y, con ella, principios de interés general para la selección objetiva e imparcial de los contratistas.

De esta forma, la ilicitud del contrato por la ocurrencia de la primera causal especial de nulidad absoluta (Ley 80/1993, artículo 44.1) no tiene por objeto la protección subjetiva ni del contratista en quien se concreta ni de los intereses subjetivos de la entidad contratante, como sujeto de derecho, sino por la protección del interés general que aquella vehicula.

En cuanto a la capacidad para contratar de las entidades estatales, ella no obedece a la concepción del derecho privado, bajo la presunción de capacidad salvo restricción de la ley (C.C., artículo 1503), por cuanto está orientada por la fundamental limitación del principio constitucional de legalidad, que exige habilitación explícita para poder actuar (C.P., artículos 121,122 y $6 .^{\circ}$ ), de tal suerte que las reglas de competencia son de orden público, indisponibles para las partes. Por eso, el Consejo de Estado considera, de manera general, que la incompetencia es una de las irregularidades más graves de la actuación públi$\mathrm{ca}$, al punto de ser objeto de declaratoria de oficio del acto que la involucra ${ }^{6}$.

Todo el tema de la competencia contractual de la Administración será de orden público y, por consiguiente, excluido de la posible ratificación por las partes, contrario al posible saneamiento de la nulidad derivada de incapacidad relativa del contratista privado (C.C., artículo 1743). La concepción decimonónica del Código Civil que asimilaba las personas de derecho público a personas incapaces bajo tutela o curaduría, en cuanto a la nulidad de sus contratos (C.C., artículo 1745), es reemplazada por la regulación de la competencia contractual definida en las reglas presupuestales y contractuales. Desde la Constitución Política (C.P.) se establece la regulación de la capacidad de contratación de las entidades públicas mediante la ley orgánica del presupuesto (C.P., artículo 352), lo que se concreta en la atribución de capacidad contractual a todos las entidades (órganos o secciones) previstas en los presupuestos general de la Nación y de las entidades territoriales, así como la regulación de la ordenación del gasto en cabeza de sus respectivos jefes, con la posibilidad de delegarla en funcionarios del nivel directivo (Decreto 111 de 1996, artículo 110). Armónicamente, el Estatuto General de Contratación identifica diversas entidades estatales que podrán contratar, remitiendo genéricamente a la ley de presupuesto, al prever que también se consideran como tales las que "la ley otorgue capacidad para celebrar contratos" (Ley 80

6 Consejo de Estado, Sala de lo Contencioso Administrativo, Sección Tercera: sent. 11/05/1999, exp. 10.196; sent. 23/07/10, exp. 16.367; sent. 28/09/2011, exp. 15.476; Consejo de Estado, Sala de lo Contencioso Administrativo, Sección Tercera, Subsección A, sent. 09/05/2012, exp. 20.968; Consejo de Estado, Sala de lo Contencioso Administrativo, Sección Tercera, Subsección B, sent. 05/12/2016, exp. 33.611; Consejo de Estado, Sala de lo contencioso administrativo, Sala Plena, sent. 12/07/2012, exp. 15.024. 
de 1993, artículo 2.1). El Estatuto también regula competencia para contratar en los diversos jefes o representantes de las entidades estatales (artículo 11) y la posible delegación en los servidores públicos que desempeñen cargos del nivel directivo o ejecutivo (artículo 12).

Por otra parte, la organización interna de las entidades privadas difiere sustancialmente de las públicas. El objeto societario, determinante de la capacidad contractual de las sociedades comerciales (C.co., artículo 99), asî como sus estructuras internas, son objeto de amplia libertad contractual en la configuración del contrato de sociedad, en el que se definen las atribuciones y facultades de los administradores y diversos órganos societarios conforme a la regulación legal de cada tipo de sociedad (C.co., artículo 110.6). Por el contrario, uno y otro aspecto son definidos de manera más rígida por las reglas de creación de las entidades estatales. La Constitución Política atribuye a la ley determinar la estructura de la Administración nacional, así como crear y modificar las distintas entidades del orden nacional, señalando sus objetivos y estructura orgánica, así como autorizar la creación de sociedades de economía mixta (artículo 150.7), concepción que es reproducida a nivel territorial, como competencia de las asambleas departamentales (artículo 300.7) y de los concejos municipales (artículo 313.6), lo que comporta la definición de los objetos (funciones) de las entidades, así como su estructura administrativa. Aunque la Constitución no define estructuras administrativas específicas, su concreción está decididamente orientada y marcada por la ley general de funcionamiento de la Administración, en la que se definen tipos de entidades estatales y esquemas generales internos (Ley 489 de 1998), tanto a nivel orgánico, como a nivel de dinámico de funcionamiento, a partir de las nociones de desconcentración (artículo $8 .^{\circ}$ ) y delegación (artículo 9. ${ }^{\circ}$ y ss.) administrativas. Por su parte, el Estatuto General de Contratación también reguló de manera especial el régimen de delegación y la concepción de desconcentración en materia contractual (artículo 12).

En síntesis, la previsión legal general de la competencia administrativa determina sustancialmente la enorme restricción del ejercicio concreto de la capacidad contractual de las entidades estatales, como lo plantea, de manera general, la Ley 489 de 1998:

Artículo 5. ${ }^{\circ}$ Competencia Administrativa. Los organismos y entidades administrativos deberán ejercer con exclusividad las potestades y atribuciones inherentes, de manera directa e inmediata, respecto de los asuntos que les hayan sido asignados expresamente por la ley, la ordenanza, el acuerdo o el reglamento ejecutivo.

Esta concepción general comprende a las entidades administrativas, así como a las regidas por el derecho privado. Por una parte, el Estatuto general de contratación concibió de manera extensa la noción de entidades estatales, incluyendo a las empresas industriales y comerciales del Estado, y a las sociedades de economía mixta con capital público mayoritario (Ley 80 de 1993, 
artículo 2.1). Por otra parte, pese a que la evolución normativa excluyó del Estatuto General de Contratación a la mayoría de las empresas industriales y comerciales del Estado y sociedades de economía mixta (Ley 1150 de 2007, artículo 14 mod.), así como a las del sector financiero público (Ley 1150 de 2007, artículo 15) y otros grupos importantes de entidades, como las empresas de servicios públicos domiciliarios (Ley 142 de 1994, artículo 31), los hospitales públicos (Ley 100 de 1993, artículo 195.6) y las universidades públicas (Ley 30 de 1993, artículo 93), entre otros, pues su funcionamiento no corresponde enteramente al de sociedades privadas. La ley general sobre las entidades públicas prescribe restricciones importantes (Ley 489 de 1998, artículos 83-93), así como las leyes especiales. La atracción hacia el régimen público de estas entidades ha significado un movimiento pendular frente a la buida del derecho administrativo bacia el derecho privado de los años noventa ${ }^{7}$, al punto que el legislador afirmó, de manera general, que pese a los regímenes excepcionales al del Estatuto General, las entidades que los aplican están obligadas a respetar los principios de la función administrativa y de la gestión fiscal y sus contratos estarán sometidos al régimen de inbabilidades e incompatibilidades previsto legalmente para la contratación estatal (Ley 1150 de 2007, artículo 13). Además, la extensión de la competencia de la jurisdicción contencioso administrativa, derivada de la concepción orgánica del Código de Procedimiento Administrativo (CPACA), atribuye al juez administrativo el juzgamiento de los contratos excluidos del Estatuto General, con escasas excepciones (artículo 104), lo que ha propiciado la aplicación de nociones propias del contrato público y su régimen de nulidades. Aunque el Consejo de Estado considera que el régimen privado de los contratos de las empresas de servicios públicos domiciliarios no permite la aplicación de las causales de nulidad previstas para los contratos estatales por el artículo 44 del Estatuto General de Contratación, en particular la nulidad de los actos previos en que se fundamenta el contrato (artículo 44.4) ${ }^{8}$, la corporación anuló un contrato por cuanto el gerente de una empresa debió obtener una autorización para contratar por parte de su junta directiva, como lo establecía el manual de contratación para los contratos de cierta cuantía. Las reglas comerciales califican este evento de extralimitación de funciones del representante legal de la sociedad, lo que genera una nulidad relativa del contrato, como bien lo tiene establecido la Superintendencia de Sociedades

7 David Andrés Serrano Salomón, "La huida del derecho administrativo en España y en Colombia. Un panorama desde las entidades descentralizadas", Revista de Derecho Público, n. ${ }^{\circ}$ 34, 2015, pp. 1-30; Pedro T. Nevado-Batalla Moreno y Carolina Bravo Vesca, "El desarrollo de actividades empresariales por la Administración: La instrumentalización de las formas del derecho privado. Breves notas sobre la 'huida del derecho administrativo' y las sociedades públicas en el sistema colombiano y español", Justitia, n. ${ }^{\circ} 8,2010$, pp. 217-252.

8 Consejo de Estado, Sala de lo Contencioso Administrativo, Sección Tercera, Subsección A, sent. 24/10/2016, exp. 45.607. 
(oficio 2020-128078 del 07/11/2011), irregularidad saneable por el paso del tiempo (2 años) o la ratificación de la junta directiva de la sociedad (C.co., artículo 900). Por el contrario, el Consejo de Estado consideró en el caso que se había incurrido en nulidad absoluta, que declaró de oficio:

el proceso de contratación se adelantó con desconocimiento del reglamento interno de contratación y, por ende, con falta de competencia del funcionario respectivo, lo cual se traduce en el desconocimiento de normas que hace parte del orden público jurídico, algunas de ellas entronizadas como principios constitucionales, específicamente el de legalidad y el de la moralidad administrativa9.

Esta misma dinámica de incompetencia insanable también está presente en el régimen constitucionales de las autorizaciones, distinto del régimen comercial. La Constitución establece la autorización especial previa que deben obtener los gobiernos nacional, departamental y local para contratar por parte de las respectivas corporaciones de elección popular (Congreso, asambleas departamentales y concejos municipales o distritales) (C.P., artículos 150.9; 300.9 y 313.3). El sentido de las autorizaciones, como modalidad de control administrativo previo de la decisión de contratar (y no de la contratación misma) ${ }^{10}$, se asemejaría, en principio, al que ejerce la junta directiva de una sociedad sobre su gerente, al autorizarlo para suscribir ciertos contratos. Pero, en el caso de las entidades públicas, ello no es objeto de saneamiento, de tal suerte que no es posible la ratificación posterior en caso de omitir la autorización, salvo el caso muy restrictivo previsto por la Carta Política para los contratos suscritos sin ella por el presidente de la República (artículo 150.14). La irregularidad constituirá una nulidad absoluta, como juzgó el Consejo de Estado con relación a un empréstito suscrito sin autorización previa del concejo municipal ${ }^{11}$. La nulidad también se concreta en los eventos en que la autorización existe pero es anulada por el Contencioso Administrativo, al concretarse así la causal $4{ }^{a}$ del artículo 44 del Estatuto General, que prescribe la nulidad del contrato cuando se declaran nulos los actos administrativos en que se fundamenten, como en el caso en el caso de la anulación de un acuerdo municipal por medio del cual se reglamentaron las tarifas del impuesto de alumbrado público y se autorizó al alcalde para contratar la concesión del mismo. El efecto futuro que normalmente tienen las sentencias de nulidad de actos no impide la declaración de nulidad

9 Consejo de Estado, Sala de lo Contencioso Administrativo, Sección Tercera, Subsección A, sent. 27/05/2015, exp. 30.690.

10 José Luis BenAVIDES, "Autorizaciones constitucionales para contratar", en José Luis Benavides (ed.), Fallos referentes en contratación estatal, Bogotá: Universidad Externado de Colombia, 2020, cap. $5^{\circ}$.

11 Consejo de Estado, Sala de lo Contencioso Administrativo, Sección Tercera, Subsección B, sent. 02/05/2016, exp. 37.438. 
del contrato que aún está en ejecución, al afectar una situación no consolida$\mathrm{da}^{12}$, como lo tiene establecido la jurisprudencia ${ }^{13}$. Otras autorizaciones pueden incluso estar previstas por regulaciones especiales, como la otorgada por la Superintendencia Bancaria (Financiera) para un contrato de capitalización, cuya ausencia generó la nulidad de una prórroga de un contrato ${ }^{14}$, o la autorización de la Dirección General de Aduanas, que era necesaria para el remate de buses que habían gozado de exención del derecho de importación ${ }^{15}$. En todos estos casos, la ausencia de la autorización prevista en la ley no permite su saneamiento o la ratificación del contrato, como en el derecho privado. Inexorablemente el contrato será nulo por vicio de competencia.

Las reglas de competencia también tienen vínculos estrechos con las reglas presupuestales y por ello el artículo 59 de la Ley Orgánica del Presupuesto (Ley 38 de 1989), hoy derogado, prescribía la invalidez los contratos con cargo a recursos de contratos de empréstito cuando estos últimos no se perfeccionaran o no fueran desembolsados, como lo declaró en un caso el Consejo de Estado $^{16}$. En este sentido, el artículo 189 del primer estatuto de contratación pública (Decreto Ley 150 de 1976) establecía la nulidad del contrato, cuando no existiere en el presupuesto correspondiente partida a la cual pudiera ser imputado el gasto que se proyectara realizar (literal d). En vigencia del Estatuto General de Contratación y después de conflictiva jurisprudencia sobre la aplicación de las reglas presupuestales para la apreciación de la existencia del contrato, es claro (para el Consejo de Estado) que el contrato que no cumple con las exigencias presupuestales, como la obtención del registro presupuestal, no solo es ajena a la apreciación de su validez, sino incluso de su existencia, relegando el problema a la ejecución del contrato, como lo establece el artículo 41 del Estatuto ${ }^{17}$. No obstante, al valorar la regla constitucional que remite a la ley orgánica del presupuesto la definición de la capacidad de las entidades para contratar, permite preguntarse si las irregularidades presupuestales no generan, en realidad, un problema de validez contractual, como ocurre en

12 Consejo de Estado, Sala de lo Contencioso Administrativo, Sección Tercera, Subsección A, sent. 29/05/2014, exp. 33.832.

13 Consejo de Estado, Sala de lo Contencioso Administrativo, Sección Tercera, auto 08/03/2007, exp. 15.052, sent. 13/03/1979, exp. SP 602.

14 Consejo de Estado, Sala de lo Contencioso Administrativo, Sección Tercera,, sent. 09/10/2003, exp. 16.657 .

15 Consejo de Estado, Sala de lo Contencioso Administrativo, Sección Tercera, sent. 07/10/1999, exp. 12.387 .

16 Consejo de Estado, Sala de lo Contencioso Administrativo, Sección Tercera, sent. 12/10/00 exp. 13.097

17 Consejo de Estado, Sala de lo Contencioso Administrativo, Sección Tercera, sent. 28/09/06, exp. 15.307; Mónica Sofía Safar Díaz, "El papel del registro presupuestal en los contratos estatales", en José Luis Benavides (ed.), Fallos referentes en contratación estatal, Bogotá: Universidad Externado de Colombia, 2020, cap. $4{ }^{\circ}$. 
el régimen español ${ }^{18} \mathrm{y}$ lo prescribe la ley, con relación a los contratos de las universidades públicas, al establecer el registro presupuestal como condición de validez de sus contratos ${ }^{19}$.

En todo caso, lo esencial es concluir que las irregularidades referidas a la competencia contractual de la Administración son insanables, generando nulidades absolutas, incluso en los contratos regidos por el derecho privado, como lo confirmó el alto tribunal, con toda rigurosidad, al declarar de oficio la nulidad de un contrato minero, al ser suscrito por el gerente de una empresa pública el mismo día en que había tomado posesión su reemplazo ${ }^{20}$.

\subsection{Vicios DEL CONSENTIMIENTO}

La valoración de las causales de nulidad relativa civil por vicios del consentimiento (C.C., artículo 1508) resulta inadaptada e incompatible con la apreciación del consentimiento de la Administración contratante. Las restricciones civiles que limitan el error constitutivo de vicio del consentimiento por referirse a la especie del contrato, la identidad específica de su objeto (C.C., artículo 1510) o su calidad esencial (artículo 1511), así como a la persona contratante, solo cuando es la causa principal del contrato (artículo 1512), adquieren connotaciones particulares cuando se valora el consentimiento de la Administración. El objeto contractual es fruto del proceso complejo de estructuración del contrato que lo precede, de tal suerte que es definido por el conjunto de actividades y documentos constitutivos de los estudios previos, según una regulación explícita y detallada (Ley 1150 de 2007, artículo 8. ${ }^{\circ}$; Decreto 1082 de 2015, artículo 2.2.1.1.2.1.1). La valoración del error no tendrá entonces la connotación restrictiva de la ley civil sino una concepción extendida en la que se apreciará el respeto o desatención de la voluminosa reglamentación obligatoria. Además la contratación estatal es siempre intuito personae, lo que hace que el contratista seleccionado no sea intercambiable, al punto que su muerte o la disolución de la persona jurídica contratista son causa legítima de terminación unilateral del contrato por parte de la administración (Ley 80 de 1993, artículo 17). De igual modo, la concepción limitada de la fuerza en el contrato privado, que vicia el consentimiento solo si ella es capaz de producir una impresión fuerte en la persona de sano juicio, distante del temor reverencial (C.C., artículo 1513), es inadaptada en el momento de apreciar las irregularidades posibles del consentimiento de la

18 Ley 9 de 2017, artículo 39.2.bi Germán García Calle, "Carencia e insuficiencia de crédito presupuestario como causa de nulidad radical de los contratos del sector público", Revista Técnica Especializada en Administración Local y Justicia Municipal, n. ${ }^{\circ} .15-16,2016$, pp. 17801800 .

19 Ley 30 de 1992, artículo 94.

20 Consejo de Estado, Sala de lo Contencioso Administrativo, Sección Tercera, Subsección B, sent. 05/12/2016, exp. 33.611. 
Administración contratante, donde el parámetro referente será la regulación normativa de la preparación del contrato. En fin, la concepción del dolo, limitada al que es obra de una de las partes sobre la otra y sin el cual no se bubiese contratado (C.C., artículo 1515), también es excesivamente restringida frente a la valoración del vicio de la voluntad de la Administración, en la medida en que no solo habrá ilicitud cuando la entidad contratante es víctima del dolo sino también cuando sus agentes y representantes contractuales actúan con dolo, lo que ocurre en los eventos de comisión de los delitos de celebración indebida de contratos tipificados en el Código Penal: violación del régimen legal o constitucional de inbabilidades e incompatibilidades (artículo 408), interés indebido en la celebración de contratos (artículo 409) y contrato sin cumplimiento de requisitos legales (artículo 410), así como en otras modalidades de corrupción y comportamientos contrarios a las competencia, sancionados hoy por la Superintendencia de Industria y Comercio, como la cartelización o los acuerdos colusorios con o sin participación de servidores públicos ${ }^{21}$.

La valoración del comportamiento de la Administración en la formación de su consentimiento se aprecia bajo criterios propios del derecho administrativo, orientados por la valoración de la legalidad de sus actos unilaterales (administrativos). La noción civil de la causa del contrato, definida como el motivo que induce al contrato (C.C., artículo 1524), se extiende en la contratación estatal a la valoración del consentimiento dado por la Administración para contratar.

El particular puede buscar los fines que quiera dentro del amplio margen que tiene para la disposición de sus intereses particulares, con el límite del orden público contractual. Por ello, la causa es relevante desde el punto de vista negativo, en cuanto motivo ilícito que induzca al contrato. Por ello también es elemento objetivo de validez del negocio, en cuanto comporta la protección de un valor de interés general externo e indisponible para las partes. Por el contrario, si el motivo inductor del contrato es lícito, su concreción es indiferente para apreciar la validez del contrato, aunque pueda ser útil para determinar o precisar el objeto, así como para interpretar el contrato. De hecho, el Código Civil tan solo exige que exista causa real del contrato, sin que ello comporte expresarla, y admite como causa válida la pura liberalidad (artículo 1524). Consecuentemente, la protección subjetiva del motivo para contratar no está centrada en la valoración de su contenido, materia propia de la autonomía y disponibilidad de los intereses privados de los contratantes, sino limitada al motivo que afecte el interés general (orden público). Otros aspectos no tendrán una restricción ni protección, sino tan solo en la preservación de la libertad al momento de expresar el consentimiento libre de vicios.

21 Andrés Palacios Lleras, "La lucha contra los carteles empresariales en la contratación estatal en Colombia", Revista Latinoamericana de Derecho, n. ${ }^{\circ}$ 3, 2019, pp. 117-134. 
En contraste, el motivo que induce a la Administración a contratar no solo será apreciado cuando es genéricamente ilícito o, más exactamente, su licitud será sistemáticamente evaluada, por cuanto las entidades estatales carecen de verdadera autonomía para definir el motivo que las induce a contratar, en la medida en que deben limitarse a lograr con el contrato los fines institucionales propios de las funciones que les son atribuidas por el derecho positivo. La causa, el motivo que induce al contrato, deviene así un ingrediente de la valoración subjetiva/objetiva de la Administración, como manifestación concreta del principio de legalidad. No siendo libre para determinar el motivo para contratar, su concreción adquiere un sentido eminentemente objetivo, distante esencialmente de la autonomía que caracteriza el consentimiento de los particulares. No en vano el artículo 3. ${ }^{\circ}$ del Estatuto General de Contratación prescribe a los servidores públicos tener en consideración que al celebrar los contratos estatales y con la ejecución de los mismos las entidades buscan el cumplimiento de los fines estatales y la continua y eficiente prestación de los servicios públicos.

La apreciación del consentimiento de la Administración para la suscripción del contrato se concreta en la determinación de la legalidad en los procesos de definición del contrato y de selección del contratista. Consecuentemente, la valoración subjetiva del consentimiento se concentra en los distintos actos producidos durante estos procesos, según las reglas de regularidad de los actos administrativos. Por ello, entre las causales de nulidad del contrato estatal cobran valor las que se relacionan con la invalidez de los actos administrativos, como la desviación de poder y la falsa motivación (Ley 80 de 1993, artículo 44.3), lo que ha permitido al Consejo de Estado caracterizar la ilicitud del contrato por desviación de poder en el propósito de favorecimiento ilícito, que pone en entredicho el proceso de contratación. El Consejo de Estado considera en efecto que

La desviación de poder en materia contractual puede ser definida como aquella función administrativa que ejercida por un servidor público se dirige a favorecer los intereses de un tercero o de sí mismo, dejando de un lado el cumplimiento de las finalidades estatales para las cuales se le otorgaron determinadas competencias en ejercicio de la actividad contractual, es decir de un lado, para la satisfacción de intereses de carácter general y, de otro para la continua, adecuada y eficiente prestación de los servicios públicos ${ }^{22}$.

En ocasiones la Corporación ha afirmado que no basta con que se eluda un procedimiento de contratación para calificar la desviación de poder, por cuanto resulta "indispensable acreditar que el contrato se celebró con una finalidad 
distinta a aquella que la ley perseguía"23. Pero, en la mayoría de casos, su valoración se restringe a la elusión del procedimiento de contratación establecido. Así, consideró la desviación de poder en un contrato de mantenimiento cuyo objeto era la demarcación y señalización de zonas de parqueo de los sótanos del Congreso de la República, fruto de un proceso en el que no se definieron reglas justas, claras y completas de selección, sustituidas por un aviso escueto de invitación a contratar publicado un día antes del contrato, al final del mes de diciembre, lo que favoreció la presentación amañada de la sola propuesta adjudicataria ${ }^{24}$. En igual sentido, la Corporación valoró la desviación de poder por los numerosos (nueve) contratos suscritos apresuradamente y de manera directa por un alcalde, al final de su período de elección, uno de los cuales incluso duplicaba el objeto de un contrato interadministrativo ${ }^{25}$, así como un caso de fraccionamiento de contratos, al suscribir uno, inicial, por un valor artificial y sustancialmente inferior al valor real de la obra contratada, con el objeto de evadir el proceso licitatorio de contratación y poder suscribir posteriormente adiciones al contrato inicial ${ }^{26}$. También hubo desviación de poder al utilizar indebidamente la flexibilidad de los contratos accesorios, que estaban previstos en el antiguo Estatuto contractual (Decreto 222 de1983) como complemento de un contrato principal y que, por ello, exigían conexidad con él (artículo 114). El Consejo de Estado consideró nulo el contrato inconexo con el principal, lo que obligaba el trámite de una licitación para seleccionar al contratista, que no se hizo ${ }^{27}$.

La desviación de poder, como decisión que se aparta de las condiciones establecidas en la ley también está presente en múltiples casos en los que la Administración evade el procedimiento licitatorio al que está obligada para suscribir amañadamente un contrato:

En relación con la causal $3 .{ }^{a}$ la jurisprudencia ha establecido de manera reiterada que cuando los funcionarios eluden los procedimientos de selección objetiva y los demás requisitos y deberes indicados por la ley, incurren en abuso o desviación de poder al apartarse de los fines que se buscan con la contratación, que no son otros que el interés público y el bienestar de la comunidad, circunstancias que a

23 Consejo de Estado, Sala de lo Contencioso Administrativo, Sección Tercera, Subsección A, sent. 30/10/2013, exp. 21.487; reiterada por la Sección Tercera, Subsección A en la sent. 12/10/2017, exp. 53.390.

24 Consejo de Estado, Sala de lo Contencioso Administrativo, Sección Tercera, Subsección C, sent. 13/02/2015, exp. 29.473 .

25 Consejo de Estado, Sala de lo Contencioso Administrativo, Sección Tercera, sent. 28/05/12, exp. 21.489

26 Consejo de Estado, Sala de lo Contencioso Administrativo, Sección Tercera, Subsección C, sent. 29/04/2015, exp. 29.201.

27 Consejo de Estado, Sala de lo Contencioso Administrativo, Sección Tercera, Subsección A, sent. 22/08/2013, exp. 22.947. 
la luz del citado Estatuto Contractual, configura la causal de nulidad absoluta del contrato $^{28-29}$.

Hay desviación de poder por comprar directamente equipos de cómputo de manera directa, por fuera de las causales taxativas previstas para este tipo de contratación o en la contratación directa de asesorías informáticas para favorecer una empresa creada con el único propósito de suscribir cuantiosos contratos con la entidad contratante ${ }^{30}$, así como en la suscripción de contrato de mandato para mantenimiento de vías terciarias, fundado artificialmente en la contratación excepcional con entidades sin ánimo de lucro (C.P., artículo 355) 31 .

La amplitud de la desviación de poder permite también calificar ilicitudes de los contratos por violación del principio de selección objetiva y las reglas de planeación. El Consejo de Estado sancionó así un contrato de concesión de aprovechamiento de residuos sólidos y recolección de basuras en un municipio, que se había soportado en la declaratoria de urgencia manifiesta por la amenaza a la salubridad pública, en razón del aumento de la población y la aparición de enfermedades vinculadas a la ausencia de un plan de gestión de las basuras en el municipio. Aunque el contrato tenía conexidad con la declaratoria de urgencia, el alto tribunal reprochó la modalidad contractual de concesión y que "la estipulación de un plazo contractual de quince años para lograr tal propósito desdibujó en lo absoluto el elemento de la urgencia que motivó su celebración por la vía de la contratación directa". El Consejo de Estado enfatizó la irregularidad al considerar que

dar en concesión por 15 años la prestación del servicio público de aseo, como producto de una declaratoria de urgencia manifiesta, sin el más mínimo soporte técnico que diera cuenta de que esa era la solución definitiva con la que se garantizaría la prestación del servicio, en condiciones óptimas, en beneficio de los habitantes de La Victoria, muy seguramente no solucionaría el problema que de inicio motivó su suscripción sino que, además, conduciría a una prolongada afectación del bien colectivo que se procuraba proteger, como en efecto ocurrió ${ }^{32}$.

28 Nota original de la sentencias del 22 de marzo de 2007, exp. 28010; del 25 de febrero de 2009, exp. 15797.

29 Consejo de Estado, Sala de lo Contencioso Administrativo, Sección Tercera, sent. 30/06/2011, exp. 19.782.

30 Consejo de Estado, Sala de lo Contencioso Administrativo, Sección Tercera, sent. 22/03/07, exp. 28.010 .

31 Consejo de Estado, Sala de lo Contencioso Administrativo, Sección Tercera, subsección B, sent. 16/11/2016, exp. 38.310.

32 Consejo de Estado, Sala de lo Contencioso Administrativo, Sección Tercera, Subsección A, sent. 16/07/2015, exp. 41.768 . 
En últimas la valoración de la licitud del consentimiento de la Administración vincula necesariamente el proceso de contratación mismo y por ello la doctrina comparada critica la distinción artificial entre la invalidez de los actos preparatorios del contrato, en particular, de la adjudicación, por una parte, y la invalidez del propio contrato, por otra parte. Aunque ellas sean diferentes, están íntimamente ligadas ${ }^{33}$, como se pone de presente en la causal cuarta de nulidad del contrato público del Estatuto General, sobre la nulidad de los actos administrativos en que se fundamenten. El formalismo de los contratos públicos condiciona así de manera esencial las particularidades de la contratación pública, como lo destaca la doctrina francesa ${ }^{34}$.

\section{Afectación del contrato}

En complemento de la afectación subjetiva del contrato, las irregularidades también pueden provenir de su causa o de su objeto ilícito. En la concepción general del contrato civil y comercial, la valoración de los intereses externos a las partes por estas causales objetivas generan nulidad absoluta del contrato (C.C., artículo 1741; C.co., artículo 899). En el contrato público, la separación entre intereses públicos e intereses subjetivos de la Administración se diluye, por la afectación generalizada de interés general a través de las diversas irregularidades subjetivas relacionadas con la Administración contratante. La causa del contrato se concreta en las finalidades perseguidas en el contrato y la causa ilícita con los propósitos ilícitos de la Administración, fusionados de manera esencial con su decisión de contratar. La ilicitud deviene así desviación de poder y falsa motivación, con afectación fundamental del consentimiento de la entidad contratante, estructurado y expresado a través del proceso de contratación, como se ha visto.

En estas condiciones, el objeto del contrato también adquiere una concepción extendida en el momento de apreciar su ilicitud. Siguiendo la concepción de Pothier en el Code Civil francés, el nuestro identifica el objeto del contrato con la prestación a la que se comprometen las partes. La definición del contrato como el acto por el cual una parte se obliga para con otra a dar, bacer o no bacer alguna cosa (C.C., artículo 1495) lleva a concebir su objeto como la o las cosas que se trata de dar, hacer o no bacer (C.C., artículo 1517). El objeto corresponde así al contenido de la obligación a la que se obligan las partes, esto es, la o las prestaciones, de tal suerte que la cosa que la materializa no se limita a un bien material (aún inmaterial), en la medida en que también puede ser una actividad.

Manuel Rebollo Puig, "La invalidez de los contratos administrativos", en Federico A. Castillo Blanco (coord.), Estudios sobre la contratación en las administraciones públicas. Albolote: Comares, 1996, p. 398; Víctor Sebastián Baca Oneto, La invalidez de los contratos públicos, Cizur Menor: Aranzadi, 2006, p. 103. 
Esta noción no deja de generar graves problemas conceptuales por las ambigüedades entre objeto del contrato y objeto de la prestación, objeto del contrato y contenido del contrato; así como entre la cosa objeto de la prestación y la prestación misma ${ }^{35}$, todo lo cual se amplifica en los contratos bilaterales, en los que las dos partes son recíprocamente deudor y acreedor. ¿El objeto del contrato sería así doble, atendiendo a las dos prestaciones principales de cada una de las partes? En el ejemplo simple de la compraventa de un bien cierto, ¿su objeto es el bien mismo objeto de la compraventa, o la prestación que recae sobre el bien? Además, la prestación es diversa para cada una de las partes: transmisión de la propiedad para el vendedori pago del precio para el comprador. El objeto del contrato no estará limitado a una de las prestaciones sino comprenderá las dos. No se trata así de un objeto doble sino de un objeto que reúne las dos prestaciones, por cuanto su esencia será la operación (única) de intercambiar cosa por precio, de transferir la propiedad del bien a cambio una remuneración.

Entendido así como operación socioeconómica, el objeto del contrato debe cumplir con requisitos previstos por el mismo Código Civil: la operación puede recaer sobre una cosa futura, si se espera que exista, debe estar en el comercio y ser determinada o determinable y, si se trata de una actividad, ella también debe ser posible física y moralmente, en el sentido de no estar prohibida por las leyes o ser contraria al orden público contractual (artículo 1518).

En la contratación pública, las dificultades de precisión conceptual del objeto se ven ampliadas al momento de valorar su ilicitud.

El Estatuto General de Contratación parte de la tipología civil y comercial de las nulidades, para identificar luego cinco que son propias de los contratos del Estado, como se transcribió al comienzo de este estudio: "los contratos del Estado son absolutamente nulos en los casos previstos en el derecho común y además cuando" (Ley 80 de 1993, artículo 44). La remisión nos lleva así a la identificación del objeto ilícito del Código Civil, prevista en su artículo 1519: "hay un objeto ilícito en todo lo que contraviene al derecho público de la Nación".

En la concepción contractual fundada en la autonomía privada para la disposición de intereses particulares de las partes, que separa las protección de sus intereses subjetivos (nulidades relativas) de la protección de los intereses generales, indisponibles para las partes contratantes (nulidades absolutas), resulta consecuente que aquellas no puedan acordar nada contario al derecho público. Por consiguiente, el contrato no puede concernir (en su objeto) la co/index.php/derpri/article/view/565; FernANDo José Aguilera Silván, "El objeto como elemento esencial del contrato", 2011 . Disponible en: http://noticias.juridicas.com/ actualidad/ [consultado el 19 de agosto de 2020]. 
transgresión de una regla de derecho público, por naturaleza indisponible para las partes, so pena de ilicitud de su objeto.

No obstante, esta concepción no es aplicable integralmente en el contrato público, so pena de extender ilimitadamente la concepción del objeto ilícito. Si el objeto del contrato está identificado con la transacción económico social acordada por las partes y, en el contrato público, ella está reglada integralmente por normas del "derecho público de la Nación", cualquier irregularidad de los elementos del contrato, extendida a todo el proceso de su formación que lo determina, conllevará, necesariamente, una contravención a una regla de derecho público de la Nación y, consecuentemente, la nulidad del contrato por objeto ilícito. El régimen entero de las nulidades de los contratos públicos se reduciría así a la ilicitud de su objeto que comprendería, a su vez, toda transgresión a cualquier norma legal y reglamentaria constitutiva del derecho público en cualquier momento de toda la fase de preparación del contrato, hasta su celebración. En el mismo sentido, sería suficiente la primera causal de nulidad absoluta prevista en el Código de Comercio, esto es, cuando el negocio jurídico contraría una norma imperativa (artículo 899.1). El carácter reglado de la actividad contractual de la Administración hace que todos los errores que se cometan en la formación del contrato, desde la idea misma de celebrarlo la constituyan, necesariamente, una contravención a alguna norma imperativa.

El Consejo de Estado evoca con frecuencia el artículo 1519 del Código Civil para la caracterización de la nulidad por circunstancias relacionadas con el objeto contractual de diversas maneras. En ocasiones, por el desconocimiento de las reglas de orden público que gobiernan los procesos de contratación, como la selección de oferta que desconoció las exigencias técnicas mínimas del pliego de condiciones ${ }^{36}$, el contrato suscrito con elución de la licitación pública ${ }^{37}$, la aplicación impropia del régimen de contratación con instituciones sin ánimo de lucro ${ }^{38}$, la contratación gravemente irregular ${ }^{39}$, la tipología errada del contrato con el propósito de eludir el proceso licitatorio que debía seguirse $^{40}$, la transgresión de la moralidad administrativa mediante la conclusión

36 Consejo de Estado, Sala de lo Contencioso Administrativo, Sección Tercera, sent 29/05/2014, exp. 29.366.

37 Consejo de Estado, Sala de lo Contencioso Administrativo, Sección Tercera, sent. 22/03/07, exp. 28.010

38 Consejo de Estado, Sala de lo Contencioso Administrativo, Sección Tercera, Subsección A sent. 11/06/2014, exp. 34.649 y Consejo de Estado, Sala de lo Contencioso Administrativo, Sección Tercera, Subsección B, sent. 16/11/2016, exp. 38.310.

39 Consejo de Estado, Sala de lo Contencioso Administrativo, Sección Tercera, Subsección A, sent. 27/03/2014, exp. 26.223 y sent. 27/05/2015, exp. 30.690.

40 Consejo de Estado, Sala de lo Contencioso Administrativo, Sección Tercera, Subsección B sent. 06/02/2019, exp. 61.720; Consejo de Estado, Sala de lo Contencioso Administrativo, Sección Tercera, Subsección C, sent. 06/05/2015, exp. 30.917. 
del contrato ${ }^{41}$, la violación de los principios de planeación, transparencia y selección objetiva ${ }^{42}$, o la contratación por funcionario incompetente: "la celebración de un contrato sin la observancia de las normas de competencia de derecho público [arriba referidas], es decir, existe objeto ilícito"43.

En otros eventos, la corporación valora el objeto mismo del contrato o sus cláusulas, para determinar que infringen reglas de orden público, de diversas formas. En ocasiones, por ser incompatibles con el tipo de contrato seleccionado, como los arrendamientos sobre bienes de uso público ${ }^{44}$, o la gestión de impuestos mediante contrato de prestación de servicios ${ }^{45}$, o el contrato accesorio sin respeto de los supuestos establecidos en la ley ${ }^{46}$. En otras oportunidades la infracción proviene de la inclusión de la cláusula de caducidad en un contrato en el que no está autorizada, como en el contrato de una licorera: "dado que las normas sobre competencia son de orden público y la entidad demandada las quebrantó con dicha cláusula, esta estipulación contiene un objeto ilícito"47. Del mismo modo, el alto tribunal considera que hay objeto ilícito en la inclusión de la cláusula de caducidad en un contrato de una empresa de servicios públicos domiciliarios, cuando este tipo de cláusulas debe estar previamente autorizado por la ley o la respectiva comisión de regulación ${ }^{48}$. De manera más amplia, el Consejo de Estado considera que hay objeto ilícito en la cláusula que reconozca un poder unilateral a la Administración contratante, como la imposición de una multa, cuando no está expresamente autorizada por la ley ${ }^{49}$. Lo mismo ha considerado con relación a la estipulación contractual que

41 Consejo de Estado, Sala de Consulta y Servicio Civil, conc. 27/08/2015, exp. 2.264.

42 Consejo de Estado, Sala de lo Contencioso Administrativo, Sección Tercera, Subsección A, sent. 29/04/2015, exp. 31.818 .

43 Consejo de Estado, Sala de lo Contencioso Administrativo, Sección Tercera, Subsección C, sent. 26/11/2015, exp. 31.151. En el mismo sentido, Consejo de Estado, Sala de lo Contencioso Administrativo, Sección Tercera, Subsección B, sent 05/12/2016, exp. 33.611.

44 Consejo de Estado, Sala de lo Contencioso Administrativo, Sección Tercera, sent. 06/06/05, exp. 12.249 y sent. 18/03/10, exp. 14.390; Consejo de Estado, Sala de lo Contencioso Administrativo, Sección Tercera, Subsección B, sent. 30/04/12, exp. 21.699; Consejo de Estado, Sala de lo Contencioso Administrativo, Sección Tercera, Subsección A, sent. 09/04/2014, exp. 33.608 .

45 Consejo de Estado, Sala de lo Contencioso Administrativo, Sección Tercera, Subsección A: sent. 30/01/13, exp. 19.083; sent. 13/05/15, exp. 29.200; sent. 09/03/2016, exp. 34.322.

46 Consejo de Estado, Sala de lo Contencioso Administrativo, Sección Tercera, Subsección A, sent. 22/08/2013, exp. 22.947.

47 Consejo de Estado, Sala de lo Contencioso Administrativo, Sección Tercera, sent. 16/02/2006, exp. 13.414.

48 Consejo de Estado, Sala de lo Contencioso Administrativo, Sección Tercera, Subsección C, sent. 04/06/2015, exp. 30.288 y sent. 28/09/11, exp. 15.476 .

49 Consejo de Estado, Sala de lo Contencioso Administrativo, Sección Tercera, sent. 07/10/09, exp. 17.936; Consejo de Estado, Sala de lo Contencioso Administrativo, Sección Tercera, Subsección A: sent. 13/02/2013, exp. 24.996; sent. 12/11/2014, exp. 29.165; Consejo 
permite a la Administración hacer efectiva una cláusula penal pactada ${ }^{50}$, o la definición de un procedimiento para imponerla ${ }^{51}$. En general, el Consejo de Estado considera que "la inclusión de cláusulas no autorizadas por ley, contraría el derecho publico", lo que conlleva un objeto ilícito, en virtud del texto civil ${ }^{52}$. En la misma lógica, también califica de objeto ilícito la cláusula que prohíbe la revisión de precios pactados por contravenir el principio de financiero del contrato, norma de derecho público ${ }^{53}$, así como la cláusula en contrario minero, que contrariaba una disposición especial del Código de Minas ${ }^{54}$.

La corporación también identificó el objeto ilícito de una prórroga, al contravenir la prohibición de prórrogas automática de los contratos de la Administración, contenida en artículo 58 del Decreto Ley 222 de $1983^{[55]}$. Desaparecida esta prohibición explícita en la Ley 80 de 1993, el Consejo de Estado reconstruyó el fundamento del objeto ilícito de la cláusula de prórroga automática en un contrato de prestación de servicios educativos:

este tipo de cláusulas contienen un objeto ilícito porque atentan contra el orden superior y, por lo tanto, suponen la existencia de una convención que riñe o pugna contra normas de orden público, de manera concreta respecto de aquellas que definen la vigencia de los contratos estatales, la solemnidad para su celebración y la posibilidad de su adición bajo estrictos términos señalados en la propia ley ${ }^{56}$.

Con la misma orientación, la corporación consideró ilícito que en un contrato de servicios "las partes acordaron que el contrato tendría una duración

de Estado, Sala de lo Contencioso Administrativo, Sección Tercera, Subsección B, sent. 09/07/2015, exp. 27.385; sent. 21/06/2018, exp. 33.684; auto 20/02/14, exp. 45.310.

50 Consejo de Estado, Sala de lo Contencioso Administrativo, Sección Tercera, Subsección B, sent. 29/08/2012, exp. 23.830; sent. 07/10/2009, exp. 18.496.

51 Consejo de Estado, Sala de lo Contencioso Administrativo, Sección Tercera, Subsección C, sent. 03/09/2015, exp. 38.247.

52 Consejo de Estado, Sala de lo Contencioso Administrativo, Sección Tercera, Subsección A, sent. 13/02/2013, exp. 24.996. Igualmente, Consejo de Estado, Sala de lo Contencioso Administrativo, Sección Tercera, sent. 07/04/2011, exp. 17.765.

53 Consejo de Estado, Sala de lo Contencioso Administrativo, Sección Tercera, Subsección A, sent. 29/07/2015, exp. 41.008 .

54 Consejo de Estado, Sala de lo Contencioso Administrativo, Sección Tercera, sent 08/03/2007, exp. 15.052

55 Consejo de Estado, Sala de lo Contencioso Administrativo, Sección Tercera, Subsección B, sent. 02/11/2016, exp. 33.396; Consejo de Estado, Sala de lo Contencioso Administrativo, Sección Tercera, Subsección C, sent. 21/11/2017, exp. 42.408.

56 Consejo de Estado, Sala de lo Contencioso Administrativo, Sección Tercera, Subsección C sent. 03/06/2015, exp. 33.953) En igual sentido: Consejo de Estado, Sala de lo Contencioso Administrativo, Sección Tercera, sent. 29/05/2013, exp. 27.875; Consejo de Estado, Sala de lo Contencioso Administrativo, Sección Tercera, Subsección A, sent. 26/02/2015, exp. 30834; Consejo de Estado, Sala de lo Contencioso Administrativo, Sección Tercera, Subsección C, sent. 03/12/2015, exp. 39828. 
indefinida, lo cual, guardadas las proporciones supondría una especie de prórroga automática del contrato" ${ }^{157}$.

El alto tribunal ha considerado, de manera más amplia, que el artículo 1519 del Código Civil significa que "toda violación a un mandato imperativo o a una prohibición de la ley, comporta un vicio que genera nulidad absoluta si, por supuesto, ella no consagra una sanción diferente", lo que le permite concluir:

Y es que las normas imperativas no son solamente aquellas que prohíben sino también las que mandan u ordenan y por ende la transgresión del orden público se presenta cuando se viola la que prohíbe, así como cuando no se observa o se desatiende la que ordena, casos todos estos que conducen a una nulidad absoluta por objeto ilícito.

Este entendimiento resulta natural y obvio, pues de no entenderse así se llegaría al absurdo de que la violación de una norma imperativa que solo manda u ordena, pero que expresamente no prohíbe, no aparejaría sanción alguna o, lo que es lo mismo, que sería una norma inane, que manda pero no manda porque puede ser inobservada sin ninguna consecuencia ${ }^{58}$.

En estas condiciones, el objeto ilícito es concebido de manera extremadamente amplia, identificado con la infracción de la ley en el proceso de contratación:

en nuestro ordenamiento jurídico todas esas anomalías se traducen en el desconocimiento de disposiciones que hacen parte del orden público jurídico, cuyo cumplimiento es incondicional e irrestricto (artículo 16 del Código Civil) ${ }^{59}$, lo cual vicia de nulidad absoluta el contrato.

En efecto, la violación de tales principios o fundamentos de orden constitucional que, técnicamente han sido entronizados como normas positivas de carácter imperativo, conduce a que el acto jurídico nazca viciado de objeto ilícito, en la medida en que, en los términos del artículo 1519 del Código Civil "Hay objeto ilícito en todo lo que contraviene al derecho público de la nación" y, desde luego, el desconocimiento de los cimientos de la función administrativa se ubica, precisamente en esta causal de nulidad absoluta y, por ende, insubsanable ${ }^{60}$.

57 Consejo de Estado, Sala de lo Contencioso Administrativo, Sección Tercera, Subsección B., sent. 30/11/2017, exp. 40.876.

58 Consejo de Estado, Sala de lo Contencioso Administrativo, Sección Tercera, Subsección C, sent. 04/06/2015, exp. 37.566. Reiterado por la Sección Tercera, Subsección C en la sent. 10/12/2015, exp. 51.489 .

59 Nota original de la sentencia. Cfr. Consejo de Estado, Sala de lo Contencioso Administrativo Sección Tercera, sentencias del 31 de enero de 1997 (exp. 10498), del 18 de marzo de 2010 (exp. 14.390) y del 21 de noviembre de 2012 (exp. 20.523), entre otras.

60 Consejo de Estado, Sala de lo Contencioso Administrativo, Sección Tercera, Subsección A, sent. 27/05/2015, exp. 30.690. 
La dificultad en la identificación precisa de nulidades objetivas que afectan directamente al contrato público se encuentra reforzada por dos temas en los que la concreción de la nulidad tiene efectos colaterales trascendentes: el primero, concierne la segunda causal especial de nulidad prevista en el Estatuto General, consistente en la celebración del contrato contra expresa probibición constitucional o legal, cuyo sentido y alcance específicos son problemáticos. El segundo, involucra la planeación del contrato y la extensión de la nulidad por objeto ilícito, por cuanto el Consejo de Estado ha considerado que las graves irregularidades en la planeación del contrato pueden afectar la licitud de su objeto, lo que ha sido muy polémico.

\subsection{CONTRATO CONTRA EXPRESA PROHibiCión CONSTITUCIONAL O LEGAL}

La extensión del objeto ilícito, con la tendencia a identificarlo con diversas contravenciones al derecho público, también propicia una lectura extendida de esta causal especial prevista en el artículo 44.2 del Estatuto General de Contratación. En sentido estricto, el contrato celebrado contra expresa prohibición solo es aquel que, en sí mismo, está prohibido por la Constitución o la ley. Así, la Carta prescribe que los bienes de uso público son inalienables (artículo 63), lo que comporta una prohibición explícita para suscribir sobre ellos un contrato que conlleve su enajenación, como lo sería una compraventa, una permuta, donación o cualquier otra modalidad negocial que involucre la disposición de la propiedad del bien. En el mismo sentido, la ley establece la prohibición de ciertos contratos celebrados por entidades públicas o, genéricamente, ciertos negocios jurídicos que incluyen convenciones accesorias a una principal. Así, dentro de los numerosos ejemplos citados arriba sobre el objeto ilícito, el antiguo estatuto contractual prohibía explícitamente pactar prórrogas automáticas en los contratos o prorrogar su plazo mediante un contrato adicional cuando el plazo se encontrara vencido (Decreto Ley 222 de 1983, artículo 58). El mismo Estatuto también establecía la prohibición explícita de pactar un arrendamiento por más de dos o cinco años sobre bienes muebles e inmuebles, respectivamente, con excepciones muy precisas (artículo 157). Todo contrato suscrito con desconocimiento de estas disposiciones comporta entonces la transgresión directa de la prohibición de suscribirlos.

El sentido estricto de la prohibición también se aprecia en la dinámica que tuvieron ciertos contratos. En una época fueron muy frecuentes los contratos de prestación de servicios para confiar al contratista tareas relacionadas con la gestión de impuestos, que comprendían actividades muy variadas, con el propósito de lograr mejorar el recaudo de la actividad, la recuperación de cartera y la gestión general de impuestos. El Consejo de Estado consideró en algunas oportunidades que esta contratación comprendía un objeto ilícito por la contravención al derecho público. Para llegar a esta conclusión, el Consejo de Estado analizó cuidadosamente las actividades confiadas a los contratistas, 
considerando que ellas comprendían ejercicio de funciones públicas, prerrogativas públicas propias de las entidades públicas y expresadas mediante actos administrativos, como la definición, revisión, liquidación y reliquidación del impuesto, lo que no podía confiarse al contratista de prestación de servicios. La sección cuarta de la corporación calificó así la ilicitud de contratar funciones de fiscalización y determinación del impuesto, actos reservados a los funcionarios públicos por el Estatuto Tributario, sin previsión de delegación a particulares ${ }^{61}$, lo que generó la invalidez de contratos para el cobro de cartera vinculada con deudas tributarias, aún cuando estuvieran limitados a trabajos de gestión de cobro prejurídico, sin inclusión de fiscalización tributaria ${ }^{62}$. El legislador reguló explícitamente la materia prohibiendo a las entidades, mediante contrato, "delegar en terceros la administración, fiscalización, liquidación, cobro coactivo, discusión, devoluciones e imposición de sanciones de los tributos por ellos administrados" (Ley 1386 de 2010, artículo $1 .^{\circ}$ )

La prohibición explícita facilitaría la declaratoria de nulidad del contrato de prestación de servicios para cobro coactivo de obligaciones a favor de secretaría de tránsito municipal ${ }^{63}$, el cobro de cartera morosa de un municipio por concepto de impuestos ${ }^{64}$, así como el contrato para la revisión, liquidación, reliquidación, cobro y recaudo jurídico procesal y extraprocesal del impuesto municipal de Industria y Comercio ${ }^{65}$.

No obstante, esta lectura restrictiva de la causal de nulidad no es la acogida por la jurisprudencia de la Sección Tercera del Consejo de Estado, al concebirla con mayor amplitud, lo que tiene efectos trascendentes, por cuanto Estatuto General permite y, más aún, ordena al jefe de la entidad estatal contratante terminar unilateralmente el contrato en el que se presenten tres causales específicas de nulidad, entre las que está esta segunda, esto es, el contrato celebrado contra expresa probibición constitucional o legal (Ley 80 de 1993, artículo 45). Aunque la jurisprudencia constitucional ${ }^{66} \mathrm{y}$ administrativa ${ }^{67}$ son enfáticas en

61 Consejo de Estado, Sala de lo Contencioso Administrativo, Sección Cuarta, sent. 22/09/2004 exp. 13.255 .

62 Consejo de Estado, Sala de lo Contencioso Administrativo, Sección Tercera, sent. 17/05/2007, rad. 00369(AP).

63 Consejo de Estado, Sala de lo Contencioso Administrativo, Sección Tercera, sent. 08/06/2011, exp. 0540-01 (AP).

64 Consejo de Estado, Sala de lo Contencioso Administrativo, Sección Tercera, Subsección A, sent. 30/01/13, exp. 19.083 .

65 Consejo de Estado, Sala de lo Contencioso Administrativo, Sección Tercera, Subsección C, sent. 16/03/2015, exp. 30.759 .

66 Corte Constitucional, sents. T-387/09 del 28 de mayo de 2009, exp. T- 2.146 .854 y T-383/09 de 28 de mayo de 2009, exp. T-2232201 y T-2232202.

67 Consejo de Estado, Sala de lo Contencioso Administrativo, Sección Tercera, sent. 02/05/07, exp. 15.599; sent. 29/08/07, exp. 15.324; sent. 18/03/2010, rad. 14.390; Consejo de Estado, Sala de lo Contencioso Administrativo, Sección Tercera, Subsección A., sent. 09/05/12, exp. 20.968 . 
explicar que la Administración no declara la nulidad del contrato, su deber de terminarlo unilateralmente comporta una enorme prerrogativa pública de valorar y declarar la existencia de la causal en el acto administrativo de terminación que, por lo demás genera la liquidación del contrato en el estado en que se encuentre, ordenada por la misma Administración (artículo 45), lo que comporta también su poder unilateral de definir la situación económica final del contrato, también de manera unilateral, si no llega a un acuerdo con su contratista (Ley 1150 de 2007, artículo 11; Ley 80 de 1993, artículo 60).

La amplitud de la concepción de la causal se puede apreciar en la valoración que realiza el Consejo de Estado sobre los contratos de arrendamiento que recaen sobre bienes de uso público, por cuanto ha considerado que la prohibición expresa se deriva de su inalienabilidad, establecida por la Constitución (artículo 63), en la medida en que el arrendamiento "no es a la postre nada distinto a la venta temporal del uso de un bien" ${ }^{\prime \prime 8}$. La concepción merece serias críticas por la desnaturalización de los derechos transmitidos al arrendatario y la naturaleza eminentemente precaria del derecho de uso del bien, esencialmente contrarios a la compraventa y a todo negocio jurídico que comporte transmisión de la propiedad, acorde con la noción de enajenación prohibida por la Carta Política ${ }^{69}$. La concepción fue, sin embargo, ratificada por una sentencia de unificación de la Sección Tercera del Consejo de Estado en la que se prohíbe el contrato de arrendamiento sobre los bienes de uso público ${ }^{70}$, cuyos fundamentos también son objeto de crítica, en la que se pone de presente que el error conceptual no impide valorar la impertinencia y carácter inadaptado del arrendamiento sobre estos bienes públicos ${ }^{71}$.

Otro factor extensivo de la concepción de la causal de nulidad ha sido el entendimiento del numeral $8 .^{\circ}$ del artículo 24 del Estatuto General de Contratación, que establece, como manifestación del principio de transparencia, el que las autoridades les será probibido eludir los procedimientos de selección objetiva y los demás requisitos previsto en el presente estatuto. En su libro sobre los Delitos de celebración indebida de contratos, Jaime Orlando Santofimio ${ }^{72}$ consideró que la prohibición comprende la elusión de todos los requisitos establecidos en el estatuto, además de los requisitos que materializan los principios de transparencia y selección

68 Consejo de Estado, Sala de lo Contencioso Administrativo, Sección primera, sent 11/11/1999, rad. 5.286.

69 Julián Andrés Pimiento EcheverRi, Teoría de los bienes de uso público, Bogotá: Universidad Externado de Colombia, 2010, pp. 218 y ss.

70 Consejo de Estado, Sala de lo Contencioso Administrativo, sent. 14/08/2018, rad. 00157 . 01 (AP) SU.

71 Julián Andrés Pimiento ECheverRI. "El aprovechamiento económico de los bienes de uso público. Reflexiones con ocasión del reciente fallo de unificación sobre la improcedencia del contrato de arrendamiento", Revista digital de Derecho Administrativo, n. ${ }^{\circ} 22,2019$, pp. 47 y ss.

72 Jaime Orlando Santofimio Gamboa, Delitos de celebración indebida de contratos. Análisis con fundamento en la teoría general del contrato estatal, Bogotá: Universidad Externado, 2000, p. 143. 
objetiva. Luego reforzaría la concepción en su Compendio de derecho administrativo, enfatizando su aporte para el entendimiento de la causal de nulidad:

Conforme con esta prohibición, constituirá requisito esencial del contrato del estado el respeto integral a los principios de interés general, transparencia y selección objetiva. Se trata de principios integralmente configuradores de requisitos legales esenciales; es decir, todas las normas y conceptos referentes a esos principios estructuran un régimen imperativo, innegociable e inderogables por la voluntad de las partes, que de llegar a desconocerse generaría nulidad absoluta ${ }^{73}$.

La concepción concibe la prohibición como el revés de la moneda del principio de legalidad y, en la medida en que todas las reglas de los procedimientos y requisitos de contratación son de orden público (en el sentido de indisponibles para las partes), cualquier violación a cualquier disposición legal o reglamentaria conllevaría violar una prohibición con ocasión de la celebración de un contrato. La causal de nulidad se extiende así a toda infracción normativa, con el agravante de que no solo el juez sino también la Administración contratante tienen la competencia para apreciarla con el objeto de declarar la nulidad o terminar unilateralmente el contrato, respectivamente.

La jurisprudencia de la Sección Tercera del Consejo de Estado se ubica entre estos dos extremos de interpretación de la causal segunda de nulidad, de tal suerte que no exige que, necesariamente, el contrato mismo suscrito ha de estar prohibido, pero tampoco considera que cualquier infracción a los principios y reglas de contratación será constitutiva de la causal, sin perjuicio, incluso, de que pueda configurarse otra causal de nulidad del contrato. Además, siguiendo la literalidad del texto del Estatuto General de Contratación (artículo 44.2), la jurisprudencia reiterada del Consejo de Estado exige que la prohibición esté establecida por una regla constitucional o legal, en sentido estricto, sin que sean pertinentes prohibiciones contenidas en normas de inferior jerarquía ${ }^{74}$, como los reglamentos o los manuales de contratación.

No obstante, la aplicación concreta no deja de generar incertidumbre sobre la apreciación de la prohibición. El Consejo de Estado ha enunciado recientemente una concepción restrictiva:

Esta causal de terminación no autoriza a la entidad contratante a dar por terminado un contrato cuando estime que al celebrarlo se violó una norma legal, así la violación pueda calificarse como grave o así pueda estimarse que ella acarrea la nulidad

73 Jaime Orlando Santofimio Gamboa, Compendio de derecho administrativo, Bogotá: Universidad Externado de Colombia, 2017, p. 683.

74 Corte Constitucional, sent. T-387/09 del 28 de mayo de 2009, exp, T- 2.146.854; Consejo de Estado, Sala de lo Contencioso Administrativo, Sección Tercera, sent. 02/05/2007, exp. 15.599 
absoluta del contrato. Lo que resulta relevante es que la norma violada contenga de manera expresa la prohibición de celebrar determinado contrato y que la entidad lo haya celebrado. Si el legislador hubiese querido otorgarle a las entidades públicas la facultad de terminar los contratos de tracto sucesivo cuando advirtieran que en su celebración se incurrió en cualquiera de las causales que pueden acarrear su anulación, no habría precisado que tal competencia solo puede ejercerse en los casos determinados de manera precisa en los numerales 1, 2 y 4 del artículo 44 (cursivas originales de la sentencia) $)^{75}$.

En el caso juzgado por esta sentencia parecía clara la desproporción de la medida administrativa de terminación unilateral, fundada en afirmaciones discutibles sobre la falta de una certificación administrativa sobre la inexistencia de personal de planta, que permitiera la contratación directa de servicios, y la falta de autorización del Concejo Municipal para comprometer vigencias futuras para el contrato, exigencia cuya pertinencia no estaba sustentada en el acto de terminación. El Consejo de Estado se limitó así a considerar que los motivos no reflejaban ninguna infracción a prohibición legal expresa, de tal suerte que la Administración debió recurrir al juez para pretender la anulación del contrato por otra causal.

Pero, esta concepción restrictiva de la causal segunda de nulidad no refleja el estado de la jurisprudencia. En muchos casos, el Consejo de Estado concibe de manera más genérica la probibición expresa, considerando que ella se configura por la violación grave de las reglas de contratación. Si bien el Consejo de Estado ha exigido en varios fallos que el contrato mismo o la contratación estén expresamente prohibidos ${ }^{76}$, son numerosos los eventos en los que admite la causal por elusiones graves y fraudulentas de los procesos competitivos, en particular de la licitación. La escogencia de la contratación directa resulta así más que la infracción de una probibición expresa, una clara intensión de soslayar el procedimiento de contratación debido, como el hecho de modificar el alcance del objeto contractual de la licitación declarada desierta para poder realizar una contratación directa ${ }^{77}$. El Consejo de Estado consideró también que la contratación directa de una obra, desconociendo el procedimiento de licitación vulneraba el deber de selección objetiva y el principio de transparencia viciando de nulidad absoluta el contrato por baberse celebrado contra expresa

75 Consejo de Estado, Sala de lo Contencioso Administrativo, Sección Tercera, Subsección B, sent. 14/11/2019, exp. 43.364 .

76 Consejo de Estado, Sala de lo Contencioso Administrativo, Sección Tercera, sent. 02/05/07, exp. 15.599; Sección Tercera, Subsección A: sent. 27/03/2014, exp. 26.223, sent. 29/04/2015, exp. 31.818; Sección Tercera, Subsección B, sent. 06/02/2019, exp. 61.720; sent. 14/05/2019, exp. 37.690; Sección Tercera, Subsección C, sent. 29/08/07, exp. 15.324; sent. 09/09/13, exp. 25.681 .

77 Consejo de Estado, Sala de lo Contencioso Administrativo, Sección Tercera, Subsección B, sent. 28/06/2012, exp. 23.966. 
probibición del artículo 24.8 de la Ley 80 de $1993^{[78]}$. La corporación también entendió configurada la causal por la realización de proceso de venta de inmueble al constatar varias graves irregularidades del proceso de contratación ${ }^{79}$, así como en la contratación de servicios de un abogado para el cobro coactivo de la cuantiosa carera morosa de un instituto público. En el caso no era necesaria una licitación, por cuanto el contrato se podía contratar directamente. No obstante, el Consejo de Estado apreció la falta de selección objetiva de una rápida contratación, sin cotizaciones previas, ni valoración de condiciones del contratista, en trámite de un solo día, lo que resultaba desproporcionado frente a la trascendencia del contrato para la entidad contratante ${ }^{80}$. El mismo razonamiento fue expuesto frente a la terminación unilateral de una concesión de explotación del monopolio de juegos de suerte y azar de Ecosalud que, por reglamentación especial, se podía contratar directamente. El alto tribunal destaca que la posible contratación directa no excluye la obligación de selección objetiva y la realización de estudios previos que valoren la viabilidad técnica, económica y financiera del contrato, todo lo cual fue omitido en el caso, incurriendo así en la causal segunda de nulidad por violación de la transparencia en la contratación estatal y los procedimientos señalados por el Estatuto de la Contratación Estatal y los reglamentos establecidos por la Administración para contratar directamente ${ }^{81}$. La infracción a la prohibición de elusión de los procedimientos de contratación (Ley 80 de 1993, artículo 24.8) también fue considerada como configuración de la causal segunda de anulación en el contrato de administración y comercialización del sorteo de una lotería ${ }^{82}$, asî como el otorgamiento directo de una concesión de alumbrado público ${ }^{83}$, o el recurrir artificialmente a los convenios con entidades privadas sin ánimo de lucro para realizar obras ${ }^{84}$.

En todos los casos, no es la prohibición expresa y explícita en norma legal lo que resulta determinante, sino la gravedad de las irregularidades de los

78 Consejo de Estado, Sala de lo Contencioso Administrativo, Sección Tercera, Subsección C, sent. 15/12/2017, exp. 55.102. En igual sentido: Consejo de Estado, Sala de lo Contencioso Administrativo, Sección Tercera, Subsección C, sent. 15/12/2017, exp. 50.045B (aclarada por sent. 08/03/2018, exp. 50.045A)

79 Consejo de Estado, Sala de lo Contencioso Administrativo, Sección Tercera, Subsección B, sent. 10/05/2017, exp. 54.324.

80 Consejo de Estado, Sala de lo Contencioso Administrativo, Sección Tercera, Subsección C, sent. 29/07/2015, exp. 30.897 .

81 Consejo de Estado, Sala de lo Contencioso Administrativo, Sección Tercera, Subsección C, sent. 04/06/2015, exp. 29.911.

82 Consejo de Estado, Sala de lo Contencioso Administrativo, Sección Tercera, Subsección B, sent. 14/03/2018, exp. 38.491.

83 Consejo de Estado, Sala de lo Contencioso Administrativo, Sección Tercera, Subsección C, sent. 15/12/2017, exp. 50.045B.

84 Consejo de Estado, Sala de lo Contencioso Administrativo, Sección Tercera, Subsección B, sent. 16/11/2016, exp. 38.310. 
procesos de contratación. En el mismo sentido, el Consejo de Estado consideró lícita la terminación de un contrato constitutivo de un montaje fraudulento mediante un contrato de denuncio y participación de bien mostrenco sobre \$35 usmD que había incautado la Policía Nacional. Resultaba evidente que los dólares tenían dueño, por cuanto la incautación dio lugar a un procedimiento de extinción de dominio por narcotráfico ${ }^{85}$.

No obstante los anteriores pronunciamientos, la gravedad de las infracciones a las reglas contractuales no siempre configura la causal para el Consejo de Estado, lo que ahonda la incertidumbre del sentido de la prohibición. Así, pese a que el alto tribunal recalificó un contrato de suministro e instalación de software para la implementación y gestión del Registro Único Nacional de Transporte (RUNT) de un instituto municipal de tránsito y trasporte, al considerar que las funciones administrativas confiadas al contratista eran propias de una concesión de servicio público, el Consejo de Estado consideró que la entidad no debió terminarlo unilateralmente, luego de que constatara la ausencia de elaboración de términos de referencia, estudios de oportunidad y conveniencia, y la realización de licitación a la que estaba obligada, por cuanto no había una prohibición expresa. El Consejo de Estado consideró pertinente la declaración de nulidad por el juez, pero no con fundamento en la causal segunda, sino en la genérica del Código Civil, que se ha visto antes (artículo 1519), al infringir reglas de derecho público imperativas sobre la realización de estudios previos y la probibición de delegar en los particulares el cobro coactivo de multas $y$ comparendos ${ }^{86}$. La infracción de reglas de contratación no sería entonces suficiente para caracterizar la causal segunda de nulidad ${ }^{87}$. El desconocimiento de los procedimientos sería más propiamente una desviación de poder, causal alterna de nulidad, como se ha visto (Ley 80 de 1993, artículo 44.3) ${ }^{88}$, al igual que en otro caso en el que se probó la violación a la selección objetiva por acordar precios por el doble del valor comercial de la prestación ${ }^{89}$.

La exigencia de prohibición expresa permitiría concluir que la irregularidad de una contratación directa de una prestación de servicios no es suficiente: "el tipo contractual (prestación de servicios profesionales) no está prohibido por la Constitución o por la ley, y el contrato -en cuanto a sus condiciones

85 Consejo de Estado, Sala de lo Contencioso Administrativo, Sección Tercera, Subsección B, sent. 14/05/2019, exp. 37.690.

86 Consejo de Estado, Sala de lo Contencioso Administrativo, Sección Tercera, Subsección B, sent. 06/02/2019, exp. 61.720 .

87 Consejo de Estado, Sala de lo Contencioso Administrativo, Sección Tercera, sent. 29/08/07, exp. 15.324 .

88 Consejo de Estado, Sala de lo Contencioso Administrativo, Sección tercera, sent. 22/03/07, exp. 28.010 .

89 Consejo de Estado, Sala de lo Contencioso Administrativo, Sección Tercera, Subsección C, sent. 28/03/2012, exp. 22.471 . 
generales- no contiene previsiones que estén expresamente prohibidas por el ordenamiento jurídico imperativo" ${ }^{\prime \prime}$.

Del mismo modo, la corporación concluyó sus consideraciones sobre la ilegalidad del acto de terminación unilateral resumiendo que: "la omisión del procedimiento legalmente previsto para la selección del contratista vicia de nulidad el contrato estatal, más no encuadra en la causal de nulidad absoluta del contrato prevista en el artículo 44.2 de la Ley 80 de 1993"1"1. La misma consideración fue expuesta por el alto tribunal frente a una contratación abiertamente irregular de una obra mediante un convenio con una cooperativa municipal (frecuentemente suscritos de manera fraudulentos para evadir las reglas de contratación pública), que fue integralmente subcontratado con una empresa particular. A pesar de que estos contratos son fuertemente criticados y sancionados por el Consejo de Estado, en el caso consideró que los motivos aducidos por la entidad para terminar el contrato unilateralmente: falta de planeación, transparencia y de selección objetiva, no constituían transgresión de una prohibición constitucional o legal expresa, propias de la causal segunda de nulidad ${ }^{92}$.

Del mismo modo, no se consideraron constitutivas de la causal de nulidad la falta de habilitación de una subdirectora del ICBF para suscribir un contrato $^{93}$, o la incompetencia de un funcionario al suscribir un contrato minero ${ }^{94}$, ni la contratación sin las vigencias futuras necesarias para un contrato de prestación de servicios con un término de tres años ${ }^{95}$ y ello, pese a que la ley es explícita en prohibir contraer obligaciones sin vigencias futuras (Decreto $111 \mathrm{de}$ 1996, artículo 71), lo que refuerza las reflexiones expuestas antes sobre los vínculos estrechos entre las reglas presupuestales y las condiciones de validez de los contratos públicos, en cuanto en este caso, como en los contratos sin disponibilidades presupuestales, se está en un claro evento de contrato celebrado contra expresa probibición legal.

90 Consejo de Estado, Sala de lo Contencioso Administrativo, Sección Tercera, Subsección A, sent. 27/03/2014, exp. 26.223.

91 Consejo de Estado, Sala de lo Contencioso Administrativo, Sección Tercera, sent 18/03/2010, rad. 14.390 .

92 Consejo de Estado, Sala de lo Contencioso Administrativo, Sección Tercera, Subsección A, sent. 29/04/2015, exp. 31.818. En el mismo sentido, frente a contratos suscritos en condiciones similares, Consejo de Estado, Sala de lo Contencioso Administrativo, Sección Tercera, Subsección A, sent. 11/06/2014, exp. 34.649, Consejo de Estado, Sala de lo Contencioso Administrativo, Sección Tercera, Subsección C, sent. 06/05/2015, exp. 30.917.

93 Consejo de Estado, Sala de lo Contencioso Administrativo, Sección Tercera, Subsección B, sent. 14/05/2019, exp. 37.690.

94 Consejo de Estado, Sala de lo Contencioso Administrativo, Sección Tercera, Subsección B, sent 05/12/2016, exp. 33.611.

95 Consejo de Estado, Sala de lo Contencioso Administrativo, Sección Tercera, Subsección C, sent. 12/08/2014, exp. 28.565 . 
Sin embargo, los numerosos fallos en sentido contrario (que admiten la causal por la irregularidad de la contratación) impiden identificar una línea jurisprudencial clara. Y ello se encuentra propiciado por la particularidad de la declaratoria de oficio de la nulidad. En la mayoría de casos, la ausencia de configuración estricta de la causal segunda no borra el que el contrato, en todo caso, sea nulo bajo otras causales que vinculan la competencia, la desviación de poder, la irregularidad del proceso de contratación o la infracción de normas de orden público. Por consiguiente, pese a que el Consejo de Estado declare la nulidad del acto administrativo de terminación del contrato, al considerar que no se configuraba la causal segunda, declara de oficio la nulidad del contrato por otra causal de nulidad, que encuentra probada ${ }^{96}$.

Las exigencias particulares de ciertas causales de nulidad resultan finalmente inanes, en la medida en que su control no impide la posibilidad y deber del juez de anular el contrato por la ocurrencia de cualquier causal de nulidad absoluta.

\subsection{Objeto ilí́cito y planeación}

La planeación tiene una importancia creciente en la contratación pública y sus reglas no solo resultan vinculantes para la Administración contratante sino también para los proponentes privados y futuros contratistas, como manifestación de su condición de colaboradores de la Administración en el logro de sus fines públicos que el Estatuto general de contratación les atribuye (artículo 3.․).

La planeación no tiene explícita consagración en la regulación del Estatuto general de contratación. La Ley 80 de 1993 no tienen ninguna mención a la planeación, lo que contrasta con el valor preponderante que ha adquirido este principio, no solo en la contratación pública sino, de manera general, en toda la gestión pública. Ello también es significativo si se tiene en cuenta el alcance general de esta ley, como Estatuto General de Contratación de la Administración Pública, y su concepción en torno a los principios básicos y esenciales que debían tener en cuenta la generalidad de las entidades del Estado al momento de contratar. Anclada en los tres principios de la contratación: transparencia, economía y responsabilidad, la Ley 80 de 1993 no concibe siquiera el principio de planeación. Algunas de sus manifestaciones se encuentran contempladas en el Estatuto, como expresión del principio de economía (artículo 25), al prescribir que las entidades deberán abrir procesos de contratación cuando existan las

96 Consejo de Estado, Sala de lo Contencioso Administrativo, Sección Tercera, sent. 18/03/2010 rad. 14.390; Consejo de Estado, Sala de lo Contencioso Administrativo, Sección Tercera, Subsección A: sent. 27/03/2014, exp. 26.223; sent. 29/04/2015, exp. 31.818; Consejo de Estado, Sala de lo Contencioso Administrativo, Sección Tercera, Subsección B: sent 05/12/2016, exp. 33.611; sent. 14/06/2018, exp. 38.850, sent. 06/02/2019, exp. 61.720 , Consejo de Estado, Sala de lo Contencioso Administrativo, Sección Tercera, Subsección C: sent. 06/05/2015, exp. 30.917; sent. 16/03/2015, exp. 30.759 . 
respectivas disponibilidades presupuestales (numeral 6), la valoración previa al proceso de contratación de la conveniencia del objeto a contratar y las autorizaciones y aprobaciones necesarias (numeral 7), así como los estudios, diseños y proyectos requeridos y los pliegos de condiciones (numeral 12 original).

Fue entonces la evolución reglamentaria y legal posterior, junto con la jurisprudencia, las que ampliaron la importancia central de la planeación para consagrarla como principio esencial de la contratación que no ha dejado de resaltar la doctrina ${ }^{97}$.

La deficiencia de planeación en la contratación fue identificada como uno los problemas importantes de la gestión contractual por el Banco Mundial en su visita de abril de 2000 (Conpes 3186 de 2002, p. 4), que sería antecedente directo de la reforma introducida por la Ley 1150 de 2007, en la que quedarían dos elementos de promoción esencial de la planeación. Por una parte, la creación de una etapa complementaria de los procesos de contratación, consistente en la elaboración de proyectos de pliegos de condiciones, que sería publicada de manera temprana antes de iniciar los procedimientos, e incluso sin obligación de iniciarlos, por cuanto su propósito era difundir las condiciones del proyecto al público con el propósito de recibir observaciones por parte de los interesados. Por consiguiente, era necesario tener listos y acompañar los pliegos con los estudios y documentos previos que sirvieron de base para su elaboración (artículo $8 .^{\circ}$ ). Por otra parte, la misma ley enunció las bases de la contratación electrónica con la creación del Sistema Electrónico para la Contratación Pública (SECOP) y la remisión al reglamento para el desarrollo de su implementación tecnológica (artículo $3 .^{\circ}$ ), con el propósito de avanzar paulatinamente en las tres fases del sistema electrónico integral de contratación en línea, previstas ya en el Conpes de 2002 (p. 48), bajo la influencia de las tendencias internacionales. A un primer estadio informativo del sistema, con la publicación electrónica de la información centralizada sobre la contratación estatal, le seguiría uno operativo, con el reemplazo del papel por medios electrónicos y la integración entre el sistema y quienes acceden a él, para llegar en una tercera fase a una función transaccional, en la que realizarían integralmente los procesos de contratación en línea. La creación posterior de la Agencia Nacional de Contratación Pública - Colombia Compra Eficiente (Decreto Ley 4170 de 2011) y el amplio desarrollo reglamentario, llevarían al incremento sustancial de la planeación en la estructuración de los procesos de contratación, a partir de una subsección del actual Decreto 1082 de 2015 titulada, justamente, "planeación" (artículo 2.2.1.1.2.1.1 ss.), en la que se enriqueció el contenido de los estudios y documentos previos de soporte para la elaboración de los proyectos

97 Jaime Orlando Santofimio Gamboa. "Aspectos relevantes de la reciente reforma a la Ley 80 de 1993 y su impacto en los principios rectores de la contratación pública", en Jaime Orlando Santofimio Gamboa y José Luis Benavides (comp.), Contratación estatal: Estudios sobre la reforma del estatuto contractual. Ley 1150 de 2007, Bogotá: Universidad Externado de Colombia, 2009, p. 42. 
de pliegos, las líneas orientadoras de los contenidos técnicos de los pliegos, los medios de difusión en línea de toda esta información y la forma de recibir retroalimentación de los interesados para mejorar la calidad de los proyectos. La actividad creciente de Colombia Compra en la creación de guías, conceptos y documentos para la difusión de mejores prácticas completaría una frondosa y expansiva regulación, con multitud de detalles para la mejor preparación de los proyectos contractuales, acordes con una buena planeación. Pese a la amplitud reconocida doctrinalmente a las competencias reglamentarias de la Agencia ${ }^{98}$, el Consejo de Estado ha proferido importantes fallos restrictivos de la fuerza vinculante de su prolífica producción ${ }^{99}$, lo que parece consolidar su esencial papel de apoyo técnico con herramientas propias del soft law, en su condición de órgano rector de contratación. Las renovadas competencias sobre los documentos tipo para licitación de obra pública de infraestructura de transporte, que le fueron conferidas por reglamento (Decreto 342 de 2019 y Decreto 2096 de 2019) de la Ley 1882 de 2018 (artículo 4. ${ }^{\circ}$ ), dejaron gran incertidumbre sobre su constitucionalidad y legalidad, frente a las precisiones que ha realizado el Consejo de Estado, lo que explicaría la adopción de la Ley 2022 de 2020, por la cual se modificó el artículo para confiar directamente competencia a la Agencia para la adopción de documentos tipo obligatorios. El Legislador evitó cuidadosamente afirmar la competencia reglamentaria de la Agencia, apenas aludida indirectamente (artículo $1{ }^{\mathrm{o}}{ }^{[100]}$ ), pero ella sí está presente: el carácter reglamentario de los pliegos tipo ${ }^{101}$ no se diluye ni desaparece en elaboración los documentos tipo para los pliegos, pese al eufemismo del legislador, al haber confiado a la Agencia la concepción de los documentos tipo de los pliegos y no los pliegos mismos, en la línea del eufemismo de la motivación de los decretos

98 Héctor Santaella Quintero. "El doble nivel, vinculante y no vinculante, de la reglamentación en la contratación pública en Colombia", en Alberto Montaña Plata y Jorge Iván Rincón Córdoba, Contratos públicos: Problemas, perspectivas y prospectivas, Bogotá: Universidad Externado de Colombia, 2017, pp. 783-821; Mónica Sofía Safar Díaz, "La reivindicación de competencias de Colombia Compra Eficiente por el Consejo de Estado: ¿nuevo alcance de la potestad reglamentaria o interpretación extensiva de la ley por la jurisprudencia?, Revista digital de Derecho Administrativo, n. ${ }^{\circ}$ 19, 2017, pp. 159-179; JorGe ENRIQue SAnTos RodríGueZ, "Las facultades reglamentarias de la Agencia Nacional de Contratación Pública Colombia Compra Eficiente", Revista digital de Derecho Administrativo, n. ${ }^{\circ}$ 19, 2017, pp. 341-347.

99 Consejo de Estado, Sala de lo Contencioso Administrativo, Sección Tercera, Subsección A sent. 11/04/2019, exp. 52.055 y Consejo de Estado, Sala de lo Contencioso Administrativo, Sección Tercera, Subsección B, sent 03/04/2020, exp. 50.199.

100 El inciso $5 .^{\circ}$ del parágrafo reformado prescribe que "serán de uso obligatorio los documentos tipo para los pliegos de condiciones de los procesos de selección [que había previsto el parágrafo original], en los términos fijados mediante la reglamentación correspondiente".

101 Cristian Andrés Díaz DíEz, "Documentos tipo obligatorios: ¿supresión de la potestad discrecional para la confección del pliego de condiciones?", Revista digital de Derecho Administrativo, n. ${ }^{\circ} 24,2020$, pp. 137 y ss. 
reglamentarios que justificaban la competencia de microrregulación la Agencia ${ }^{102}$. La competencia atribuida es así incluso mayor que la de definición de los pliegos tipo, por cuanto la ley no permite identificar la naturaleza, variedad, contenido ni alcance de los documentos tipo que concebirá la Agencia, lo que siembra dudas importantes sobre la constitucionalidad del la misión confiada, no solo por la ausencia de competencia reglamentaria general de la Agencia, que ha venido reforzando la jurisprudencia administrativa, sino también por las competencias legislativas que podrían deducirse de la indefinición y amplitud de los documentos tipo, que comprenderá, a juicio de la Agencia, todos los requisitos que "representen buenas prácticas contractuales que procuren el adecuado desarrollo de los principios que rigen la contratación" (artículo $1 .^{\circ}$ ).

Con este gran refuerzo por las exigencias de planeación en toda la actividad contractual también se ha incrementado la apreciación de la responsabilidad por sus deficiencias. El Consejo de Estado ha concebido el pliego de condiciones como un acto administrativo mixto: unilateral, en el proceso de contratación, bilateral durante la ejecución del contrato, "porque no pocas de las condiciones del mismo se integran al negocio jurídico, como verdaderas cláusulas de este $^{\prime \prime 103}$. Consecuentemente, la jurisprudencia concibió que los incumplimientos derivados de la planeación, por naturaleza anteriores al contrato en su fase de estructuración, como los estudio y diseños, podían generar dificultades en la ejecución del contrato. La responsabilidad de la entidad contratante estaría así comprometida por el incumplimiento de sus obligaciones, como lo juzgó el alto tribunal con ocasión de las obras complementarias originadas en las aguas subterráneas que amenazaban la estabilidad de un tanque de almacenamiento de agua, objeto de una obra contratada. El Consejo de Estado destacó el fundamento de la responsabilidad contractual de la Administración por incumplimiento en sus obligaciones de planeación:

Se destaca que la falta de planeación por parte de las entidades públicas, incide tanto en la etapa de formación del contrato, pero más significativamente en la etapa de ejecución, momento en el cual las omisiones de la Administración por falta de estudios y diseños definitivos generan serias consecuencias, que llevan a modificar las cantidades de obra y las condiciones técnicas inicialmente pactadas, generan el incremento de los costos del proyecto y, en el más grave de los casos, conducen a la paralización de las obras o a su imposibilidad de realizarlas por falta de los recursos requeridos, situaciones que generalmente culminan en cuantiosos pleitos judiciales ${ }^{104}$.

102 Ibíd., pp. 147 y ss

103 Consejo de Estado, Sala de lo Contencioso Administrativo, Sección Tercera, sent. 30/11/2006, exp. 18.059; Consejo de Estado, Sala de lo Contencioso Administrativo, Sección Tercera, Subsección C, sent. 19/08/2011, exp. 20.457.

104 Consejo de Estado, Sala de lo Contencioso Administrativo, Sección Tercera, sent. 29/08/2007, exp. 15.469 . 
De la misma forma, el Consejo de Estado calificó la responsabilidad contractual de la Administración por los sobrecostos que soportó el contratista en la reconstrucción de una calle, al encontrar redes de servicios públicos que obligaron procesos de excavación más exigentes frente a los previstos en el contrato. Para la corporación, "fue la falta de un adecuado diseño, imputable exclusivamente al IDU, lo que dificultó el normal desarrollo de los trabajos"105.

Esta tradicional valoración de la planeación, como obligación de la administración contratante y generadora de su responsabilidad contractual, ha sido reformulada por la jurisprudencia administrativa debido al incremento de las exigencias de planeación y su condición de principio esencial de toda la gestión contractual.

Este principio no se encuentra sistemáticamente consagrado en el ordenamiento jurídico colombiano [observaba el Consejo de Estado en el 2006 en una acción popular, con ocasión de la construcción de una villa olímpica departamental en el año 2000], pero su esencia se encuentra expresada en varios preceptos constitucionales y en diferentes normas del estatuto contractual ${ }^{106}$.

Por esta vía, las exigencias anteriores a la suscripción del contrato, como la obtención previa de licencias y permisos administrativos "no solo se constituyen en un elemento del principio de planeación, sino en un requisito de legalidad imprescriptible para posibilitar la realización del objeto contractual del cual se trate ${ }^{\prime \prime 107}$. Las condiciones adecuadas de planeación no son apreciadas así por sus consecuencias perjudiciales para la ejecución correcta del contrato, sino por su exigibilidad para la suscripción misma del contrato. Del terreno de la responsabilidad por la ejecución del contrato, el Consejo de Estado pasa así al terreno de la validez jurídica del contrato mismo. El reproche sobre la indebida estructuración del contrato no se realiza por los daños generados al contratista sino por haber recorrido incorrectamente el camino que llevó a la suscripción del contrato, lo que lleva naturalmente la valoración al terreno de las nulidades contractuales.

Muchos de los eventos analizados antes con ocasión de la valoración subjetiva de la nulidad por desviación de poder o fallas graves en los procedimientos de contratación son reforzados también por el Consejo de Estado al considerar las fallas graves de planeación que ellos comportan. La urgencia

105 Consejo de Estado, Sala de lo Contencioso Administrativo, Sección Tercera, sent. 07/09/2000, exp. 12.024 .

106 Consejo de Estado, Sala de lo Contencioso Administrativo, Sección Tercera, auto 13/03/2006 exp. $00090 \mathrm{AP}$.

107 Consejo de Estado, Sala de lo Contencioso Administrativo, Sección Tercera, sent. 05/06/2008, exp. 8.031 
manifiesta artificialmente utilizada ${ }^{108}$, los contratos suscritos apresuradamente al final del período de gobierno de un alcalde ${ }^{109}$, el contrato accesorio artificial ${ }^{110}$, el contrato adicional por encima del valor permitido por la ley ${ }^{111}$, el fraccionamiento de los contratos ${ }^{112}$, la prórroga automática pactada que crea término indefinido del contrato ${ }^{113}$ y la selección del contratista fundada en indefiniciones del pliego ${ }^{114}$ son todos ejemplos en los que el Consejo de Estado destaca las fallas graves de planeación. Y, reforzado por el enorme poder del juez de declaración oficiosa de la nulidad contractual absoluta, creado por la ley civil desde 1936 (C.C., artículo 1742 mod., artículo 2. ${ }^{\circ}$ Ley 50 de 1936) y ratificado por el Estatuto General de Contratación (artículo 45), el juez administrativo no está sujeto a que las partes planten la nulidad en la demanda o su contestación, por cuanto el legislador prescribe, no una facultad, sino el deber de declarar la nulidad absoluta cuando aparezca de manifiesto en el contrato ${ }^{115}$. Incluso, tampoco está limitado el juez por protecciones esenciales de las partes, como el principio de la non reformatio in pejus por apelante único ${ }^{116}$, ni la caducidad del medio de control contractual, por cuanto la decisión no es fruto de la acción ejercida por las partes, lo que amplía la competencia de la declaración oficiosa a la prescripción extraordinaria decenal (C.C. artículo 2532 modificado) ${ }^{117}$.

108 Consejo de Estado, Sala de lo Contencioso Administrativo, Sección Tercera, Subsección A, sent. 16/07/2015, exp. 41.768 .

109 Consejo de Estado, Sala de lo Contencioso Administrativo, Sección Tercera, Subsección B, sent. 28/05/12, exp. 21.489 .

110 Consejo de Estado, Sala de lo Contencioso Administrativo, Sección Tercera, Subsección A, sent. 22/08/2013, exp. 22.947.

111 Consejo de Estado, Sala de lo Contencioso Administrativo, Sección Tercera, sent. 28/04/10, exp. 17.935

112 Consejo de Estado, Sala de lo Contencioso Administrativo, Sección Tercera, Subsección C, sent. 29/04/2015, exp. 29.201

113 Consejo de Estado, Sala de lo Contencioso Administrativo, Sección Tercera, Subsección C, sent. 03/06/2015, exp. 33.953 .

114 Consejo de Estado, Sala de lo Contencioso Administrativo, Sección Tercera, Subsección B, sent. 29/05/2014, exp. 29.366.

115 Consejo de Estado, Sala de lo contencioso Administrativo, Sección Tercera, sent. 07/10/1999, exp. 12.387; sent. 06/06/2005, exp. 12.249; Sección Tercera, Subsección A, sent. 27/03/2014, exp. 26.223; sent. $11 / 06 / 2014$, exp. 34.649; sent. 29/04/2015, exp. 31.818; sent. 05/07/2018, exp. 37.834; Consejo de Estado, Sala de lo Contencioso Administrativo, Sección Tercera, Subsección B, sent. 29/05/2014, exp. 29.366; sent. 05/12/2016, exp. 3.3611.

116 Consejo de Estado, Sala de lo Contencioso Administrativo, Sección Tercera, Subsección A sent. 09/05/2012, exp. 20.968; Consejo de Estado, Sala de lo Contencioso Administrativo, Sección Tercera, Subsección C, sent. 24/01/2011, exp. 16.326; sent. 13/06/2013, exp 26.637; sent. 13/02/2015, exp. 29.473; sent. 16/03/2015, exp. 30.759; sent. 29/04/2015, exp. 29.201 .

117 Consejo de Estado, Sala de lo Contencioso Administrativo, Sección Tercera, sent. 06/06/2005, exp. 12.249; sent. 16/02/2006, exp. 13.414; Consejo de Estado, Sala de lo Contencioso Administrativo, Sección Tercera, Subsección B, sent 05/12/2016, exp. 33.611; Consejo 
El juez se desplaza así del terreno del contencioso subjetivo de responsabilidad por el incumplimiento de obligaciones contractuales, que le ha planteado el contratista con su demanda, al terreno objetivo del control de legalidad del contrato, a través del reproche por el desconocimiento de condiciones de su validez. El control objetivo de la licitud del contrato estatal y los fines públicos por él vehiculados modifican la condición del contratista como de víctima del incumplimiento de la Administración contratante por su indebida planeación del contrato, exigiéndole ahora cargas de diligencia al momento de ofertar, ante un proyecto contractual mal estructurado. Su condición de futuro colaborador de la Administración contratante, resaltada desde la definición de las finalidades del contrato estatal (Ley 80 de 1993, artículo 3.), y la posibilidad que tiene hoy de conocer anticipadamente las bases técnicas del proyecto contractual a través de la publicación del pliego y los estudios previos, constituyen el revés de la moneda del principio de transparencia. La publicidad de los proyectos no es solo así un deber de buen comportamiento de la Administración, mediante la presentación clara de las bases técnicas del futuro contrato, sino también un carga para el proponente quien, en su condición de experto en la materia, ha de verificar su consistencia, carga reforzada con la evolución normativa que lo vincula tempranamente en la fase de observaciones al proyecto de pliego y amplifica las oportunidades de observaciones sobre el pliego y la definición de los riesgos contractuales, a través de audiencias especiales creadas para ello (Ley 80 de 1993, artículo 30.4 (modificado); Decreto 1082 de 2015, artículo 2.2.1.2.1.1.2).

En estas condiciones, el Consejo de Estado llegó lejos en su valoración objetiva del contrato, al considerar que las fallas de planeación podían incluso afectar la licitud del objeto contractual. En una obra para la construcción de un puente peatonal, que no se pudo realizarse por cuanto la entidad no puso a disposición los terrenos correspondientes, el contratista demandó a la entidad por incumplimiento contractual, pretendiendo la indemnización de los daños consecuentes, consistentes en los materiales comprados y el personal dispuesto para la obra, así como las ganancias que no pudo obtener ante la frustrada ejecución del contrato. El Consejo de Estado cambió la orientación del litigio, observando las finalidades de la contratación pública en la satisfacción de intereses de carácter general, lo que impone ceñirse a los principios de la función administrativa y los principios de la contratación, y el cumpliendo los deberes de planeación, determinantes para la definición de aspectos esenciales del futuro contrato. En el caso, una obra cuya realización se preveía en escasos 60 días, sin haber siquiera entrado en negociaciones de 
compra con los propietarios de los terrenos sobre los que se realizaría, ponía en evidencia graves problemas de planeación que hacían evidente la imposibilidad de realización del objeto en el tiempo acordado. En la celebración misma del contrato infringía la ley no solo la administración, sino también el contratista al haber presentado propuesta para una proyecto irrealizable. El Consejo de Estado concluye así que:

en este caso se estará en presencia de un contrato con objeto ilícito porque se está contraviniendo las normas imperativas que ordenan que los contratos estatales deben estar debidamente planeados para que el objeto contractual se pueda realizar y finalmente se pueda satisfacer el interés público que envuelve la prestación de los servicios públicos ${ }^{118}$.

Más delicada fue una decisión cercana a esta, en otro caso de obra con fallas de planeación. A diferencia del anterior, se trataba un viaducto vial, obra importante, que tuvo problemas en su ejecución porque la entidad no había comprado unos predios de la obra, lo que generó retardo importante en su realización, aunque la obra se realizó completamente y fue recibida por la entidad. El contratista demandó la responsabilidad contractual de la entidad contratante por los costos originados en la mayor permanencia inicial, debido a la contratación de personal y disponibilidad de maquinaria. Pero, al resolver la apelación de la sentencia de primera instancia, que había dado razón al contratista y condenado a la entidad contratante, el Consejo de Estado la revocó, para declarar, igualmente, que el irrespeto de los mandatos normativos de planeación "comporta[ba] una transgresión al orden legal que conduce a la nulidad absoluta del contrato por ilicitud del objeto porque de acuerdo con el derecho común esto es lo que se configura en todo acto que contraviene al derecho público"1119, según la definición genérica que vimos consagra el artículo 1519 del Código Civil. No pudiendo cumplirse la obra, en el plazo de catorce meses estipulado en el contrato en razón a la falta de compra previa de parte de los terrenos, su objeto era ilícito.

La consecuencia para el contratista era grave. Acudiendo a la jurisdicción para reclamar la indemnización de un daño sufrido por el incumplimiento de la Administración, obtuvo la anulación del contrato de manera oficiosa, lo que le cerraba la puerta al pronunciamiento sobre su incumplimiento e indemnización de los consecuentes perjuicios que exigen un contrato válido. Pese a que conceptualmente podría plantearse la responsabilidad por la culpa

118 Consejo de Estado, Sala de lo Contencioso Administrativo, Sección Tercera, Subsección C, sent. 24/04/2013, exp. 27.315.

119 Consejo de Estado, Sala de lo Contencioso Administrativo, Sección Tercera, Subsección C, sent. 13/06/2013, exp 26.637. 
en la celebración del contrato anulado ${ }^{120}$, nuestra jurisprudencia se centra exclusivamente en el carácter objetivo de la declaración de nulidad, con las consecuencias igualmente objetivas de las restituciones recíprocas fruto del efecto retroactivo de la nulidad (C.C., artículo 1746) y el reconocimiento de las prestaciones ejecutadas hasta la declaratoria de nulidad, consagrado en la regulación especial de la contratación estatal (Ley 80 de 1993, artículo 48). Incluso la modificación introducida por el legislador a raíz de las irregularidades en la contratación de concesiones, con ocasiones de los actos de corrupción en el caso Odebrecht (Ley 1882 de 2018, artículo 20) y la muy importante modulación de la Corte Constitucional en su declaratoria de exequibilidad condicional (sentencia C-207/19), plantean el problema del reconocimiento de compensaciones y no propiamente de responsabilidad ${ }^{121}$.

Ante la gravedad de la situación, con una obra culminada y en funcionamiento para la comunidad, el contratista interpuso tutela contra la sentencia del Consejo de Estado, argumentando su imposibilidad de conocer la deficiencia de planeación al momento de presentar la oferta, incumplimiento atribuible por completo a la culpa de la entidad contratante, quien era responsable exclusivo de la adquisición de los predios. La Sección Cuarta del Consejo de Estado tuteló el derecho del contratista, al observar que la sentencia no hizo valoración alguna de las cláusulas contractuales, sino de los errores anteriores al contrato, por la falta de planeación de la entidad. Pese a reconocer la importancia trascendente de la planeación en los contratos público, la Sección Cuarta observo que la violación del principio de planeación no es causal autónoma o directa de nulidad del contrato y no encaja en la concepción del objeto ilícito, referido, necesariamente, a la ilicitud de las prestaciones acordadas por las partes en el contrato y no a la ilicitud de los comportamientos anteriores al contrato mismo:

una cosa es la etapa previa a la celebración del contrato, incluida la etapa de planeamiento [observa la Sección Cuarta], y otra es el momento de la celebración del contrato. Al ajustarse el contrato queda configurado el objeto, esto es, quedan descritas las mutuas obligaciones y son estas las que deben estar libres de ilicitud: no deben ser contrarias a una expresa prohibición legal, deben respetar el orden público y las buenas costumbres ${ }^{122}$.

Consecuentemente, ordenó a la Sección Tercera resolver de nuevo el recurso de apelación, bajo el entendido de que el desconocimiento del principio de

120 Catherine Thibierge, Nulidad, restituciones y responsabilidad, Bogotá: Universidad Externado de Colombia, 2010.

121 Aida Patricia Hernández Silva, "Las restituciones mutuas en la contratación estatal", en José Luis Benavides (ed.), Fallos referentes en contratación estatal, Bogotá: Universidad Externado de Colombia, 2020, cap. 8.

122 Consejo de Estado, Sala de lo Contencioso Administrativo, Sección Cuarta, sent. 21/08/14, exp. 01919-00 (AC). 
planeación no genera nulidad del contrato por objeto ilícito. Pese al cumplimiento de la sentencia de tutela, la Sección Tercera no deja de criticarla enfáticamente, al insistir en su nueva sentencia sobre el fundamento del objeto ilícito en la regla del Código Civil, recordando variada jurisprudencia y doctrina en la que se expone que el incumplimiento de normas de orden público al contratar tiene trascendencia en la ilicitud del objeto. Con todo, la nueva sentencia también modula (en principio) su afirmación, al aclarar que no toda transgresión de planeación genera nulidad, sino en los eventos en que son tan graves que

desde el momento de su celebración ponen en evidencia que el objeto contractual no podrá ejecutarse o que su ejecución va a depender de situaciones indefinidas o inciertas por necesitar de decisiones de terceros o que los tiempos de ejecución acordados no podrán cumplirse y por ende habrá de sobrevenir el consiguiente detrimento patrimonial de la entidad contratante por los sobrecostos en que habrá de incurrirse por el retardo ${ }^{123}$.

Las observaciones del Consejo de Estado frente a la trascendencia del interés general en la preservación de las reglas de planeación, cuya concreción define el objeto y alcance del contrato, ponen de presente que el objeto en el contrato público no puede reducirse a la descripción de las prestaciones de las partes para valorar su licitud exclusivamente a partir de Estas. Una concepción así restringida recuerda la ambigüedad destacada en la primera parte de este estudio sobre el objeto del contrato frente al objeto de las obligaciones de las partes. En el contrato público ello irá aún más lejos.

En el contrato entre particulares, como se ha visto, la apreciación sobre la validez del objeto se limita a la licitud de lo que las partes están acordando bajo la concepción de la libre disposición de sus intereses, con el solo límite de que lo convenido no sea contrario al orden público. Por el contrario, en el contrato público, la definición misma del objeto contractual no es asunto de autonomía verdadera de las partes, en la medida en que, por una parte, el objeto debe cumplir con unas finalidades públicas (Ley 80 de 1993, artículo 3..$^{\circ}$ ) $y$, por otra, su construcción y definición surge de un complejo proceso previo, definido por principios y reglas de obligatorio cumplimiento que vinculan todo el proceso de planeación. En este sentido, el respeto de los postulados para la estructuración del proyecto sí resulta determinante de la regularidad del objeto contractual.

Las particularidades del contrato público llevan así a exacerbar las dificultades de definición de fronteras conceptuales, en la medida en que el objeto contractual vincula los fines de la entidad para definirlo, pero también elementos

123 Consejo de Estado, Sala de lo Contencioso Administrativo, Sección Tercera, Subsección C., sent. 20/10/2014, exp.24.809. 
subjetivos del contrato, por cuanto, como también se ha expuesto antes, la capacidad de la entidad estatal contratante vincula la apreciación de sus competencias específicas para definir el objeto contractual, y su consentimiento involucra la formación de su voluntad mediante el proceso de contratación, que incluye también la estructuración del contrato. Las críticas a la concepción del Consejo de Estado han llevado a proponer una solución fundada, no en la ilicitud del objeto contractual, sino de la causa ilícita ${ }^{124}$, con lo cual se acentúa de dificultad de identificación conceptual y refuerza la necesidad de una valoración especializada de los elementos de validez del contrato público.

Las dificultades conceptuales explican también la supresión de la causa (por lo menos formalmente) como elemento de validez de los contratos en la trascendente reforma reciente del título de las obligaciones del Código Civil francés ${ }^{125}$ que tanta influencia tuvo en nuestra concepción contractual (privada y pública), y la necesidad de una valoración profunda de las irregularidades de la planeación capaces de afectar la licitud del objeto contractual en la contratación estatal. En efecto, pese a que en la sentencia de cumplimiento de la tutela el Consejo de Estado considera que no toda irregularidad de planeación lleva a la afectación del objeto, en realidad, la caracterización del extracto transcrito de las que sí resultarían trascendentes genera enorme incertidumbre sobre su alcance concreto, en la medida en que comprende variados ejemplos que permitirían incluir cualquier falla en la estructuración del proyecto, como los muy numerosos y variados errores que impidan cumplir el plazo acordado en el contrato.

El contraste de los dos casos aquí expuestos es ilustrativo de valoraciones distintas posibles. Mientras en el puente peatonal el plazo de ejecución acordado resultaba imposible y los errores de planeación llevaron a que el proyecto no se ejecutara, en el segundo caso los errores generaron dificultades importantes en el proyecto y costos cuantiosos, pero la obra se realizó con las condiciones técnicas previstas y cumple con los objetivos públicos. De igual modo, aunque la conciencia de las partes (en particular del contratista) sobre la ilicitud no es trascendente para la valoración de la licitud de su objeto por su carácter objetivo, como lo recalca el Consejo de Estado ${ }^{126}$, las cargas derivadas de la buena fe precontractual sí pueden ayudar a la apreciación de la irregularidad

124 Juan Carlos Expósito Vélez, "La planeación y validez del contrato estatal", en Alberto Montaña Plata y Jorge Iván Rincón Córdoba (eds.), Contratos públicos: problemas, perspectivas y prospectivas, Bogotá: Universidad Externado de Colombia, 2017, p. 108.

125 Olivier Deshayes, Thomas Genicon e Yves-Marie Laithier. Réforme du droit des contrats, du régime général et de la s preuve des obligations, París: Lexis-Nexis, 2016, p. 170; RODRIGO MOMBERC URIBE, "La reforma al derecho de obligaciones y contratos en Francia. Un análisis preliminar", Revista Chilena de Derecho Privado, n. ${ }^{\circ} .24$, julio, 2015.

126 Consejo de Estado, Sala de lo Contencioso Administrativo, Sección Tercera, Subsección C, sent. 24/04/2013, exp. 27.315. 
del objeto. La imposibilidad de realizar el puente peatonal en escasos sesenta días era evidente para cualquier ingeniero diligente al momento de decidir postular en el proyecto del puente peatonal. Por el contrario, resulta irracional pensar que, al preparar su oferta, el oferente de una obra compleja tiene la carga de diligencia de verificar la existencia y regularidad de todos los títulos de propiedad de los terrenos sobre los que se realizará la obra pública.

La concreción del objeto del contrato público involucra sin duda al proceso de estructuración del proyecto, pero su ilicitud no podría verse afectada sino en casos particularmente graves. La preservación del contrato en la medida de lo posible es expuesta como principio y orientación de valoración de su licitud jurídica en el derecho comparado, teniendo en cuenta los valores públicos involucrados con su ejecución efectiva, lo que plantean un complejo y paradójico equilibrio entre legalidad y seguridad jurídica ${ }^{127}$. Consecuentemente, la mayoría de problemas se abordarán en el plano de la responsabilidad contractual y no en el terreno de la nulidad contractual.

\section{Conclusiones}

La fuente de las nulidades del contrato público en el derecho común tiene limitaciones importantes. Las particularidades aparecen desde la aplicación de la división esencial bipartita de su clasificación, fundada en la protección de intereses individuales e intereses públicos que se ven afectados con las irregularidades de los elementos de validez del contrato. Los intereses generales vinculados al contrato estatal no se limitan a los elementos objetivos tradicionales del contrato: objeto y causa lícitos, por cuanto los ellos se relacionan con valores subjetivos de la Administración contratante e incluso, en algunos casos, ni siquiera se limitan a la protección subjetiva de la capacidad del contratista, como ocurre en sus incapacidades derivadas de inhabilidades e incompatibilidades, fundadas en intereses públicos relacionados con la transparencia, la neutralidad y la objetividad de la decisión administrativa. La capacidad contractual, aplicada a las entidades contratantes, difiere sustancial y esencialmente de la concepción civilista fundada en la libre disponibilidad y autonomía de los interés particulares, invirtiendo la regla general y esencial de la presunción de capacidad salvo disposición legal en contrario (C.C., artículo 1503), con la necesidad de habilitación legal expresa, reflejo del principio de legalidad de las entidades públicas (C.P., artículos 6. ${ }^{\circ}, 121$ y 122). A partir de esta distancia esencial, las diferencias en otros aspectos se desgranan sucesivamente. La protección de la expresión de la voluntad libre de vicios, natural consecuencia de la protección del contrato privado como acto de generación de obligaciones

127 Jean-FrançOIS Lafaix, Essai sur le traitement des irrégularités dans les contrats de l'Administration, París: Dalloz, 2009, pp. 35 y ss. 
fundado en la libre disposición de intereses particulares, no puede tener el mismo sentido que en la voluntad de la Administración. Siempre reglada hacia fines públicos, para los cuales el contrato no es sino un simple instrumento, incluso en los eventos de libre selección de su contratista, la Administración tiene condicionada su voluntad al respeto de principios esenciales de toda gestión pública, como la selección objetiva, la transparencia, la imparcialidad o la moralidad pública. La autonomía de la voluntad afirmada por el legislador en el Estatuto General de Contratación (artículos 32 y 40) es finalmente muy particular en su aplicación a la Administración contratante y siempre sufre el filtro de las finalidades públicas, como lo ha expuesto la jurisprudencia constitucional (sentencia C-949/01). La apreciación de los vicios de la voluntad que afecta el consentimiento en el contrato privado se transforma así en vicios de la competencia de la Administración, que incluye su expresión de voluntad en sus modalidades anormales de desviación de poder y falsa motivación. De manera general, los vicios afectan la expresión de la voluntad en los procesos de contratación, de tal suerte que las irregularidades en del contrato vinculan de manera esencial los procedimientos de selección.

Las particularidades trastocan así todos las causales de nulidad y su clasificación del derecho privado ${ }^{128}$. Las subjetivas de incapacidad relativa y vicios del consentimiento, generadoras de nulidades relativas, tienen variantes objetivas calificadas de nulidades absolutas en la contratación estatal, con la tipología especial del artículo 44 del Estatuto General de Contratación, como las inhabilidades e incompatibilidades (numeral $10^{\circ}$ ), la desviación de poder (numeral $3 .^{\circ}$ ) o anulación de los actos en que se fundamentan (numeral $4 .^{\circ}$ ), constitutivos de actos previos que concretan la formación de la voluntad y consentimiento de la Administración en los procesos de contratación.

En realidad, todas las expresiones de nulidad en el contrato estatal tienen carácter objetivo cuando se refieren a la Administración, reduciendo las posibilidades de nulidades relativas a las que conciernen exclusivamente a los particulares contratistas y, con ello, convirtiendo en exóticos los eventos de saneamiento de nulidad, a punto de desconocerse ejemplos jurisprudenciales.

$Y$ en cuanto a los elementos objetivos del contrato cuyos vicios generan nulidad absoluta en el contrato privado por vincular intereses generales externos e indisponibles para las partes (causa y objeto ilícitos), su concreción en el contrato público también se muestra particular. La restricción de la causa ilícita civil a los propósitos inaceptables perseguidos por los particulares carece de mayor sentido en el contrato público en el que las finalidades de la contratación están definidas por el legislador y orientadas, de manera determinante, hacia el cumplimiento de los fines públicos (Ley 80 de 1993, artículo 3. ${ }^{\circ}$. Los propósitos restringidos del contrato público también orientan de 
manera determinante su objeto, con la extensión formidable que le ha dado la jurisprudencia administrativa por su vínculo esencial con el principio de planeación, pese a los reveses que ha sufrido la jurisprudencia de la Sección Tercera del Consejo de Estado.

En estas condiciones, aunque el problema no se ha abordado de manera explícita por la jurisprudencia administrativa, cabe preguntarse si el régimen de nulidades del Estatuto General de Contratación se limita a los contratos que están regidos por él o si, de manera extensiva, se aplica a todos los contratos de las diversas entidades del Estado, con independencia de su régimen jurídico. Aunque el Consejo de Estado ha considerado en algunos casos la exclusión del régimen de nulidades de la Ley 80 de 1993, por tratarse de contratos regidos por el derecho privado, en otros, sin abordar el tema, aplica las reglas del Estatuto en los contratos que lo excluyen. Formalmente podría ponerse de presente que el texto del artículo 44 del Estatuto general no se refiere a las nulidades de los contratos estatales sino, genéricamente, a las de los contratos del Estado. Materialmente, se impone constatar que las particularidades expuestas en este análisis, referidas a las reglas de competencia, a la formación particular de la voluntad de las entidades públicas, sus finalidades vinculas al interés general, la disposición de recursos públicos a través del contrato y tantas otras, están igualmente presentes en todos los contratos de la Administración pública, aunque la ley prescriba que se rigen por el derecho privado. La persistente atracción hacia el derecho público de estos contratos por parte de la jurisprudencia administrativa permitiría contextualizar el sentido de la aplicación de los principios de la función administrativa a todos los contratos de la Administración, sin perjuicio de su régimen privado o especial, como prescribe el artículo 13 de la Ley 1150 de 2007. En últimas, ello no conlleva concebir que todo contrato comporta una función administrativa, lo que incluso no ocurre de manera generalizada en los contratos estatales regidos por el Estatuto General, sino que los principios que rigen la función administrativa consagrados por la Constitución (artículo 209), que reflejan orientaciones generales de toda actividad de la Administración (igualdad, moralidad, eficacia, economía, celeridad, imparcialidad, publicidad) impregnan de manera profunda todos los contratos de todas las entidades públicas, sin importar su régimen jurídico especial, que no podría borrar por ello las particularidades de toda ejecución de recursos públicos, ni la imposibilidad de perseguir fines particulares de los servidores públicos, ni aun fines subjetivos exclusivos de la entidad, como ocurre en el caso de las empresas públicas que no pueden ignorar que sus fines comerciales no borran los propósitos del bien común inherentes a todas las decisiones que las conciernen.

Las particularidades de las nulidades en la contratación pública se ponen también en evidencia con una jurisprudencia compleja y en muchos aspectos inestable, que difícilmente a caracterizado con claridad la consistencia de la especificidad de estos contratos. Tal vez será necesario asumir, de manera 
integral, que los valores, fines y el funcionamiento mismo de la Administración contratante generan categorías particulares para la valoración de los contratos públicos. Ello permitiría estructurar mejor los criterios de identificación de las nulidades en los contratos estatales, así como las particularidades de los efectos de la nulidad, tema que sería necesario abordar en otro estudio.

\section{BIBLIOGRAFÍA}

Aguilera Silván, Fernando José. "El objeto como elemento esencial del contrato", 2011. Disponible en: http://noticias.juridicas.com/actualidad/ [consultado el 19 de agosto de 2020].

Aponte Díaz, Iriana. "Las fallas de planeación y su incidencia en el contrato estatal de obra". Revista digital de Derecho Administrativo, n. ${ }^{\circ} 11,2014$.

Baca Oneto, Víctor Sebastián. La invalidez de los contratos públicos. Cizur Menor: Aranzadi, 2006.

BenAVIDES, José LuIs. "Autorizaciones constitucionales para contratar". En José LuIS BENAVIDES (ed.), Fallos referentes en contratación estatal. Bogotá: Universidad Externado de Colombia, 2020.

Bourdon, PierRe. Le contrat administratif illégal. París: Dalloz, 2014.

Deshayes, Olivier, Thomas Genicon e Yves-Marie Laithier. Réforme du droit des contrats, du régime général et de la s preuve des obligations. París: Lexis-Nexis, 2016.

Díaz Díez, Cristian Andrés. "Documentos tipo obligatorios: isupresión de la potestad discrecional para la confección del pliego de condiciones?". Revista digital de Derecho Administrativo, n. ${ }^{\circ}$ 24, 2020.

EXPósito Vélez, Juan Carlos. "La planeación y validez del contrato estatal". En Alberto Montaña Planta y Jorge Iván Rincón Córdoba (eds.), Contratos públicos: problemas, perspectivas y prospectivas. Bogotá: Universidad Externado de Colombia, 2017.

Flori, ROBERTO. "El problema del objeto el contrato en la tradición civil". Revista de Derecho Privado, n. ${ }^{\circ} 12-13,2007$. Disponible en: https://revistas.uexternado.edu. co/index.php/derpri/article/view/565

García Calle, Germán. "Carencia e insuficiencia de crédito presupuestario como causa de nulidad radical de los contratos del sector público". Revista Técnica Especializada en Administración Local y Justicia Municipal, n.‥ 15-16, 2016.

Hernández Silva, Aida Patricia. "Las restituciones mutuas en la contratación estatal". En José Luis Benavides (ed.), Fallos referentes en contratación estatal. Bogotá: Universidad Externado de Colombia, 2020. 
LAFAIX, JEAN-FrançOIS. Essai sur le traitement des irrégularités dans les contrats de l'Administration. París: Dalloz, 2009.

Momberg Uribe, Rodrigo. "La reforma al derecho de obligaciones y contratos en Francia. Un análisis preliminar", Revista Chilena de Derecho Privado, n. ${ }^{\circ}$ 24, 2015.

Nevado-Batalla Moreno, Pedro T. y Carolina Bravo Vesga. "El desarrollo de actividades empresariales por la Administración: La instrumentalización de las formas del derecho privado. Breves notas sobre la 'huida del derecho administrativo' y las sociedades públicas en el sistema colombiano y español", Justitia, n. ${ }^{\circ}$ 8, 2010.

PALACIOS LlerAS, ANDRÉS. "La lucha contra los carteles empresariales en la contratación estatal en Colombia". Revista Latinoamericana de Derecho, n. ${ }^{\circ}$ 3, 2019.

Pimiento Echeverri, Julián Andrés. Teoría de los bienes de uso público. Bogotá: Universidad Externado de Colombia, 2010.

Pimiento Echeverri, Julián Andrés. "El aprovechamiento económico de los bienes de uso público. Reflexiones con ocasión del reciente fallo de unificación sobre la improcedencia del contrato de arrendamiento". Revista digital de Derecho Administrativo, n. $^{\circ} 22,2019$.

Pouyaud, Dominique. La nullité des contrats administratifs. París: LGDJ, 1991.

Rebollo Puig, Manuel, "La invalidez de los contratos administrativos". En Federico A. Castillo Blanco (coord.), Estudios sobre la contratación en las administraciones públicas. Albolote: Comares, 1996.

Safar Díaz, Mónica Sofía. "El papel del registro presupuestal en los contratos estatales". En José Luis Benavides (ed.), Fallos referentes en contratación estatal. Bogotá: Universidad Externado de Colombia, 2020.

Safar Díaz, Mónica Sofía. "La reivindicación de competencias de Colombia Compra Eficiente por el Consejo de Estado: ¿nuevo alcance de la potestad reglamentaria o interpretación extensiva de la ley por la jurisprudencia?". Revista digital de Derecho Administrativo, n. ${ }^{\circ} 19,2017$.

Santaella Quintero, Héctor. "El doble nivel, vinculante y no vinculante, de la reglamentación en la contratación pública en Colombia". En Alberto Montaña Planta y Jorge Iván Rincón Córdoba, Contratos públicos: Problemas, perspectivas y prospectivas. Bogotá: Universidad Externado de Colombia, 2017.

Santofimio Gamboa, Jaime Orlando. Delitos de celebración indebida de contratos. Análisis con fundamento en la teoría general del contrato estatal. Bogotá: Universidad Externado, 2000.

Santofimio Gamboa, Jaime Orlando. "Aspectos relevantes de la reciente reforma a la Ley 80 de 1993 y su impacto en los principios rectores de la contratación pública". 
En Jaime Orlando Santofimio Gamboa y José Luis Benavides (comp.), Contratación estatal: Estudios sobre la reforma del estatuto contractual. Ley 1150 de 2007. Bogotá: Universidad Externado de Colombia, 2009.

Santofimio Gamboa, Jaime Orlando. Compendio de derecho administrativo. Bogotá: Universidad Externado de Colombia, 2017.

Santos Rodríguez, Jorge Enrique. "Las facultades reglamentarias de la Agencia Nacional de Contratación Pública Colombia Compra Eficiente". Revista digital de Derecho Administrativo, n. ${ }^{\circ}$ 19, 2017.

Serrano Salomón, David Andrés. "La huida del derecho administrativo en España y en Colombia. Un panorama desde las entidades descentralizadas". Revista de Derecho Público, n. ${ }^{\circ} 34,2015$.

Thibierge, Catherine. Nulidad, restituciones y responsabilidad. Bogotá: Universidad Externado de Colombia, 2010.

JURISPRUDENCIA

\section{Corte Constitucional}

Corte Constitucional, sent. T-387/09 del 28 de mayo de 2009, exp, T- 2.146.854.

Corte Constitucional, sent. T-383/09 del 28 de mayo de 2009, exp. T-2232201 y T-2232202.

\section{Consejo de Estado}

Consejo de Estado, Sala de lo Contencioso Administrativo, Sección Tercera, sent. 13/03/1979, exp. SP 602.

Consejo de Estado, Sala de lo Contencioso Administrativo, Sección Primera, sent. 03/12/1997, exp. 4.179 .

Consejo de Estado, Sala de lo Contencioso Administrativo, Sección Tercera, sent. 11/05/1999, exp. 10.196 .

Consejo de Estado, Sala de lo Contencioso Administrativo, Sección Tercera, sent. 07/10/1999, exp. 12.387.

Consejo de Estado, Sala de lo Contencioso Administrativo, Sección Primera, sent. 11/11/1999, rad. 5.286

Consejo de Estado, Sala de lo Contencioso Administrativo, Sección Tercera, sent. 07/09/2000, exp. 12.024 
Consejo de Estado, Sala de lo Contencioso Administrativo, Sección Tercera, sent. 12/10/2000, exp. 13.097.

Consejo de Estado, Sala de lo Contencioso Administrativo, Sección Tercera, sent. 09/10/2003, exp. 16.657.

Consejo de Estado, Sala de lo Contencioso Administrativo, Sección Cuarta, sent. 22/09/2004, exp. 13.255

Consejo de Estado, Sala de lo Contencioso Administrativo, Sección Tercera, sent. 06/06/2005, exp. 12.249.

Consejo de Estado, Sala de lo Contencioso Administrativo, Sección Tercera, auto 24/09/2005, exp. 2.458 AP.

Consejo de Estado, Sala de lo Contencioso Administrativo, Sección Tercera, sent. 16/02/2006, exp. 13.414 .

Consejo de Estado, Sala de lo Contencioso Administrativo, Sección Tercera, auto 13/03/2006, exp. 00090 AP.

Consejo de Estado, Sala de lo Contencioso Administrativo, Sección Tercera, sent. 28/09/2006, exp. 15.307.

Consejo de Estado, Sala de lo Contencioso Administrativo, Sección Tercera, sent. 30/11/2006, exp. 18.059 .

Consejo de Estado, Sala de lo Contencioso Administrativo, Sección Tercera, auto 08/03/2007, exp. 15.052 .

Consejo de Estado, Sala de lo Contencioso Administrativo, Sección Tercera, sent. 22/03/2007, exp. 28.010.

Consejo de Estado, Sala de lo Contencioso Administrativo, Sección Tercera, sent. 17/05/2007, rad. 00369(AP).

Consejo de Estado, Sala de lo Contencioso Administrativo, Sección Tercera, sent. 05/06/2008, exp. 8.031.

Consejo de Estado, Sala de lo Contencioso Administrativo, Sección Tercera, sent. 29/08/2007, exp. 15.469.

Consejo de Estado, Sala de lo Contencioso Administrativo, Sección Tercera, Subsección C, sent. 29/08/2007, exp. 15.324.

Consejo de Estado, Sala de lo Contencioso Administrativo, Sección Tercera, sent. de 25/02/2009, exp. 15797. 
Consejo de Estado, Sala de lo Contencioso Administrativo, Sección Tercera, sent. 07/10/2009, exp. 17.936

Consejo de Estado, Sala de lo Contencioso Administrativo, Sección Tercera, Subsección B, sent. 07/10/2009, exp. 18.496.

Consejo de Estado, Sala de lo Contencioso Administrativo, Sección Tercera, sent. 18/03/2010, exp. 14.390 .

Consejo de Estado, Sala de lo Contencioso Administrativo, Sección Tercera, sent. 28/04/2010, exp. 17.935.

Consejo de Estado, Sala de lo Contencioso Administrativo, Sección Tercera, sent. 23/07/2010, exp. 16.367.

Consejo de Estado, Sala de lo Contencioso Administrativo, Sección Tercera, Subsección C, sent. 24/01/2011, exp. 16.326.

Consejo de Estado, Sala de lo Contencioso Administrativo, Sección Tercera, sent. 07/04/2011, exp. 17.765 .

Consejo de Estado, Sala de lo Contencioso Administrativo, Sección Tercera, sent. 08/06/2011, exp. 0540-01 (AP).

Consejo de Estado, Sala de lo Contencioso Administrativo, Sección Tercera, Subsección C, sent. 19/08/2011, exp. 20.457.

Consejo de Estado, Sala de lo Contencioso Administrativo, Sección Tercera, Subsección C, sent. 28/09/2011, exp. 15.476.

Consejo de Estado, Sala de lo Contencioso Administrativo, Sección Tercera, Subsección C, sent. 28/03/2012, exp. 22.471.

Consejo de Estado, Sala de lo Contencioso Administrativo, Sección Tercera, Subsección B, sent. 30/04/12, exp. 21.699.

Consejo de Estado, Sala de lo Contencioso Administrativo, Sección Tercera, Subsección A, sent. 09/05/2012, exp. 20.968.

Consejo de Estado, Sala de lo Contencioso Administrativo, Sección Tercera, sent. 28/05/2012, exp. 21.489 .

Consejo de Estado, Sala de lo Contencioso Administrativo, Sección Tercera, Subsección B, sent. 28/06/2012, exp. 23.966.

Consejo de Estado, Sala de lo Contencioso Administrativo, Sala Plena, sent. 12/07/2012, exp. 15.024 
Consejo de Estado, Sala de lo Contencioso Administrativo, Sección Cuarta, sent. 12/07/2012, exp. 17.892 .

Consejo de Estado, Sala de lo Contencioso Administrativo, Sección Tercera, Subsección B, sent. 29/08/2012, exp. 23.830 .

Consejo de Estado, Sala de lo Contencioso Administrativo, Sección Tercera, Subsección A, sent. 30/10/2013, exp. 21.487;

Consejo de Estado, Sala de lo Contencioso Administrativo, Sección Tercera, Subsección A, sent. 22/08/2013, exp. 22.947.

Consejo de Estado, Sala de lo Contencioso Administrativo, Sección Tercera, Subsección C, sent. 24/04/2013, exp. 27.315

Consejo de Estado, Sala de lo Contencioso Administrativo, Sección Tercera, Subsección A, sent. 30/01/13, exp. 19.083.

Consejo de Estado, Sala de lo Contencioso Administrativo, Sección Tercera, Subsección. A, sent. 22/08/2013, exp. 22.947.

Consejo de Estado, Sala de lo Contencioso Administrativo, Sección Tercera, Subsección A, sent. 13/02/2013, exp. 24.996.

Consejo de Estado, Sala de lo Contencioso Administrativo, Sección Tercera, Subsección A, sent. 13/02/2013, exp. 24.996.

Consejo de Estado, Sala de lo Contencioso Administrativo, Sección Tercera, Subsección C, sent. 24/04/2013, exp. 27.315.

Consejo de Estado, Sala de lo Contencioso Administrativo, Sección Tercera, sent. 29/05/2013, exp. 27.875.

Consejo de Estado, Sala de lo Contencioso Administrativo, Sección Tercera, Subsección A, sent. 30/01/13, exp. 19.083.

Consejo de Estado, Sala de lo Contencioso Administrativo, Sección Tercera, Subsección C, sent. 09/09/13, exp. 25.681.

Consejo de Estado, Sala de lo Contencioso Administrativo, Sección Tercera, Subsección A, sent. 22/08/2013, exp. 22.947.

Consejo de Estado, Sala de lo Contencioso Administrativo, Sección Tercera, Subsección C, sent. 24/04/2013, exp. 27.315.

Consejo de Estado, Sala de lo Contencioso Administrativo, Sección Tercera, Subsección C, sent. 13/06/2013, exp 26.637. 
Consejo de Estado, Sala de lo Contencioso Administrativo, Sección Tercera, Subsección B, auto 20/02/2014, exp. 45.310.

Consejo de Estado, Sala de lo Contencioso Administrativo, Sección Tercera, Subsección A, sent. 09/04/2014, exp. 33.608.

Consejo de Estado, Sala de lo Contencioso Administrativo, Sección Tercera, Subsección C, sent. 29/05/2014, exp. 29.366.

Consejo de Estado, Sala de lo Contencioso Administrativo, Sección Tercera, Subsección A, sent. 29/05/2014, exp. 33.832.

Consejo de Estado, Sala de lo Contencioso Administrativo, Sección Tercera, Subsección C, sent. 12/08/2014, exp. 28.565.

Consejo de Estado, Sala de lo Contencioso Administrativo, Sección Cuarta, sent. 21/08/2014, exp. 01919-00 (AC).

Consejo de Estado, Sala de lo Contencioso Administrativo, Sección Tercera, Subsección C, sent. 20/10/2014, exp.24.809.

Consejo de Estado, Sala de lo Contencioso Administrativo, Sección Tercera, Subsección C, sent. 13/02/2015, exp. 29.473.

Consejo de Estado, Sala de lo Contencioso Administrativo, Sección Tercera, Subsección A, sent. 26/02/2015, exp. 30834.

Consejo de Estado, Sala de lo Contencioso Administrativo, Sección Tercera, Subsección C sent. 16/03/2015, exp. 30.759 .

Consejo de Estado, Sala de lo Contencioso Administrativo, Sección Tercera, Subsección C, sent. 29/04/2015, exp. 29.201.

Consejo de Estado, Sala de lo Contencioso Administrativo, Sección Tercera, Subsección A, sent. 29/04/2015, exp. 31.818 .

Consejo de Estado, Sala de lo Contencioso Administrativo, Sección Tercera, Subsección C, sent. 06/05/2015, exp. 30.917.

Consejo de Estado, Sala de lo Contencioso Administrativo, Sección Tercera, Subsección A sent. 13/05/15, exp. 29.200.

Consejo de Estado, Sala de lo Contencioso Administrativo, Sección Tercera, Subsección A, sent. 27/05/2015, exp. 30.690.

Consejo de Estado, Sala de lo Contencioso Administrativo, Sección Tercera, Subsección C, sent. 03/06/2015, exp. 33.953. 
Consejo de Estado, Sala de lo Contencioso Administrativo, Sección Tercera, Subsección C, sent. 04/06/2015, exp. 29.911.

Consejo de Estado, Sala de lo Contencioso Administrativo, Sección Tercera, Subsección C, sent. 04/06/2015, exp. 30.288.

Consejo de Estado, Sala de lo Contencioso Administrativo, Sección Tercera, Subsección C, sent. 04/06/2015, exp. 37.566.

Consejo de Estado, Sala de lo Contencioso Administrativo, Sección Tercera, Subsección B, sent. 09/07/2015, exp. 27.385.

Consejo de Estado, Sala de lo Contencioso Administrativo, Sección Tercera, Subsección A, sent. 16/07/2015, exp. 41.768.

Consejo de Estado, Sala de lo Contencioso Administrativo, Sección Tercera, Subsección C, sent. 29/07/2015, exp. 30.897.

Consejo de Estado, Sala de lo Contencioso Administrativo, Sección Tercera, Subsección A, sent. 29/07/2015, exp. 41.008.

Consejo de Estado, Sala de Consulta y Servicio Civil, conc. 27/08/2015, exp. 2.264.

Consejo de Estado, Sala de lo Contencioso Administrativo, Sección Tercera, Subsección C, sent. 03/09/2015, exp. 38.247.

Consejo de Estado, Sala de lo Contencioso Administrativo, Sección Tercera, Subsección C, sent. 26/11/2015, exp. 31.151.

Consejo de Estado, Sala de lo Contencioso Administrativo, Sección Tercera, Subsección C, en la sent. 10/12/2015, exp. 51.489.

Consejo de Estado, Sala de lo Contencioso Administrativo, Sección Tercera, Subsección A, sent. 09/03/2016, exp. 34.322.

Consejo de Estado, Sala de lo Contencioso Administrativo, Sección Tercera, Subsección B, sent. 02/05/2016, exp. 37.438 .

Consejo de Estado, Sala de lo Contencioso Administrativo, Sección Tercera, Subsección A, sent. 24/10/2016, exp. 45.607.

Consejo de Estado, Sala de lo Contencioso Administrativo, Sección Tercera, Subsección B, sent. 02/11/2016, exp. 33.396;

Consejo de Estado, Sala de lo Contencioso Administrativo, Sección Tercera, Subsección B, sent. 16/11/2016, exp. 38.310. 
Consejo de Estado, Sala de lo Contencioso Administrativo, Sección Tercera, Subsección B, sent 05/12/2016, exp. 33.611.

Consejo de Estado, Sala de lo Contencioso Administrativo, Sección Tercera, Subsección B, sent. 10/05/2017, exp. 54.324.

Consejo de Estado, Sala de lo Contencioso Administrativo, Sección Tercera, Subsección A, sent. 12/10/2017, exp. 53.390.

Consejo de Estado, Sala de lo Contencioso Administrativo, Sección Tercera, Subsección C, sent. 21/11/2017, exp. 42.408.

Consejo de Estado, Sala de lo Contencioso Administrativo, Sección Tercera, Subsección B, sent. 30/11/2017, exp. 40.876.

Consejo de Estado, Sala de lo Contencioso Administrativo, Sección Tercera, Subsección C, sent. 15/12/2017, exp. 55.102.

Consejo de Estado, Sala de lo Contencioso Administrativo, Sección Tercera, Subsección C, sent. 15/12/2017, exp. 50.045B

Consejo de Estado, Sala de lo Contencioso Administrativo, Sección Tercera, Subsección C, sent. 08/03/2018, exp. 50.045A.

Consejo de Estado, Sala de lo Contencioso Administrativo, Sección Tercera, Subsección B, sent. 14/03/2018, exp. 38.491.

Consejo de Estado, Sala de lo Contencioso Administrativo, Sección Tercera, Subsección B, sent. 14/06/2018, exp. 38.850.

Consejo de Estado, Sala de lo Contencioso Administrativo, Sección Tercera, Subsección B, sent. 21/06/2018, exp. 33.684.

Consejo de Estado, Sala de lo Contencioso Administrativo, Sección Tercera, Subsección A, sent. 05/07/2018, exp. 37.834.

Consejo de Estado, Sala de lo Contencioso Administrativo, sent. 14/08/2018, rad. 00157-01 (AP) SU.

Consejo de Estado, Sala de lo Contencioso Administrativo, Sección Tercera, Subsección B, sent. 06/02/2019, exp. 61.720.

Consejo de Estado, Sala de lo Contencioso Administrativo, Sección Tercera, Subsección A, sent. 11/04/2019, exp. 52.055.

Consejo de Estado, Sala de lo Contencioso Administrativo, Sección Tercera, Subsección B, sent. 14/05/2019, exp. 37.690. 
Consejo de Estado, Sala de lo Contencioso Administrativo, Sección Tercera, Subsección B, sent. 14/11/2019, exp. 43.364 .

Consejo de Estado, Sala de lo Contencioso Administrativo, Sección Tercera, Subsección B, sent. 03/04/2020, exp. 50.199. 